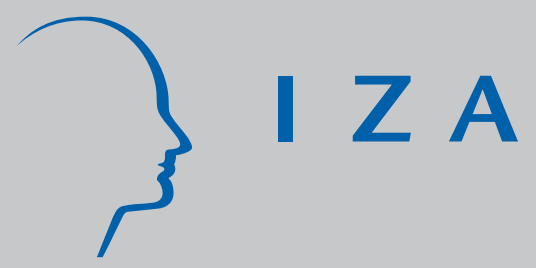

IZA DP No. 1284

How Equal Are Educational Opportunities?

Family Background and Student Achievement in Europe and the United States

Ludger Woessmann

September 2004 


\title{
How Equal Are Educational Opportunities? Family Background and Student Achievement in Europe and the United States
}

\author{
Ludger Woessmann \\ ifo, University of Munich, \\ CESifo and IZA Bonn
}

\section{Discussion Paper No. 1284 \\ September 2004}

\author{
IZA \\ P.O. Box 7240 \\ 53072 Bonn \\ Germany \\ Phone: +49-228-3894-0 \\ Fax: +49-228-3894-180 \\ Email: iza@iza.org
}

\begin{abstract}
Any opinions expressed here are those of the author(s) and not those of the institute. Research disseminated by IZA may include views on policy, but the institute itself takes no institutional policy positions.

The Institute for the Study of Labor (IZA) in Bonn is a local and virtual international research center and a place of communication between science, politics and business. IZA is an independent nonprofit company supported by Deutsche Post World Net. The center is associated with the University of Bonn and offers a stimulating research environment through its research networks, research support, and visitors and doctoral programs. IZA engages in (i) original and internationally competitive research in all fields of labor economics, (ii) development of policy concepts, and (iii) dissemination of research results and concepts to the interested public.
\end{abstract}

IZA Discussion Papers often represent preliminary work and are circulated to encourage discussion. Citation of such a paper should account for its provisional character. A revised version may be available directly from the author. 


\title{
ABSTRACT \\ How Equal Are Educational Opportunities? Family Background and Student Achievement in Europe and the United States*
}

This paper estimates the effects of family-background characteristics on student performance in the US and 17 Western European school systems. Family background has strong effects both in Europe and the United States, remarkably similar in size. France and Flemish Belgium achieve the most equitable performance for students from different family backgrounds, and Britain and Germany the least. Equality of opportunities is unrelated to countries' mean performance. Quantile regressions show little variation in family-background effects across the ability distribution in most countries.

JEL Classification: I21, J62, H52

Keywords: equality of opportunity, student performance, family background, TIMSS, equity-efficiency tradeoff, intergenerational mobility

\author{
Ludger Woessmann \\ ifo Institute for Economic Research \\ University of Munich \\ Poschingerstr. 5 \\ 81679 Munich \\ Germany \\ Email: woessmann@ifo.de
}

\footnotetext{
${ }^{*}$ I appreciate the hospitality of the Directorate General for Economic and Financial Affairs (DG ECFIN) of the European Commission in Brussels during my Visiting Fellowship, which allowed me to finalize most of this paper. During the initial stages of this research, I also benefited from the hospitality of PEPG at Harvard University and the NBER in Cambridge, MA. I would like to thank Sascha Becker, Anders Björklund, Thomas Fuchs, Charlotte Lauer, George Psacharopoulos, and Emiliana Vegas as well as seminar participants at the European Commission, the Universities of Konstanz, Linz, Mainz, and Munich (CES), the RWI in Essen, and the DIPF in Frankfurt for valuable comments and discussion, and Andreas Ammermüller for research assistance in the construction of the countryspecific databases.
} 


\section{Introduction}

Equality of opportunity for all citizens is a major concern in all open societies (cf., e.g., Roemer 1998). An important foundation for the future civil, social, and economic opportunities of citizens is laid in the education system. The importance of educational performance for future income and productivity of individuals and societies has been documented by a large literature (cf., e.g., Bishop 1992; Card 1999). However, no consistent evidence is available to what extent different countries achieve equal educational opportunities for children from different family backgrounds. Such evidence would be useful both because it could reveal an important feature of each country's equality of opportunity and because the comparison of equality of educational opportunity across countries may lead to a better understanding of how it may be achieved and why different countries achieve it to a different extent. This paper aims to present estimates of the extent of equality of opportunity in education in Western European countries and the United States that are directly comparable across countries.

The topic of equality of educational opportunity relates to the extensive economic literature on intergenerational earnings mobility, which looks at the relationship in earnings between parents and their children (cf. Solon 1999 for a survey). Because of the strong relationship between education and earnings, there should be a strong mapping between intergenerational mobility in education outcomes and intergenerational mobility in earnings. But while Solon (2002) shows how the literature on earnings mobility suffers from limitations in the comparability of data and concepts across countries, this paper uses internationally comparable data on students' educational performance to yield readily comparable estimates of educational mobility. Measures of intergenerational educational mobility have the additional advantage of providing contemporaneous evidence on family-background effects for children currently in school, while earnings mobility can only be measured with sufficient precision once the children have been in the labor market for a considerable period of time.

Evidence of substantial earnings returns to quantitative measures of education, like years of schooling, is abundant (cf. the surveys by Card 1999 and Ashenfelter et al. 1999). ${ }^{1}$ But the earnings returns to qualitative measures of education, like scores on cognitive achievement tests, seem to be even higher (Boissiere et al. 1985; Bishop 1989, 1992) and increasing over time (Murnane et al. 1995). Furthermore, while returns to educational quantity decrease with

1 The impact of family background on educational quantity in Britain is studied by Ermisch and Francesconi (2001). 
an individual's time in the labor market, returns to educational quality increase (Altonji and Pierret 2001). Even among school dropouts, i.e. students with the lowest educational quantity, there are substantial earnings returns to basic cognitive skills (Tyler et al. 2000). ${ }^{2}$ This suggests that qualitative measures of education such as cognitive achievement tests are better indicators for future economic opportunities than quantitative measures of education such as years of formal schooling.

Therefore, this paper uses data from a large international comparative student achievement test - the Third International Mathematics and Science Study (TIMSS) - to estimate the impact of parental education and other measures of family background on children's test scores. Thus, for the purposes of this paper, the extent of equality of opportunity in education is measured by the size of the effect that several measures of students' family background have on their performance on standardized achievement tests in math and science.

In effect, the estimates of equality of educational opportunity are derived by estimating the "home production" part of education production functions. ${ }^{3}$ The TIMSS database contains both achievement data for representative samples of middle-school students in 17 Western European school systems (in 15 countries) and the United States, and abundant familybackground data available from student background questionnaires. The fact that the same data-generating process was implemented in all countries allows for a direct comparison of estimated family-background effects across the European countries and with the United States. ${ }^{4}$

The paper is structured as follows. Section 2 introduces the database and presents the empirical model. As a general rule, the discussion in this paper will focus on student performance in math, as this is generally viewed as being most readily comparable across countries. Math achievement has also been shown to be most strongly related to productivity

\footnotetext{
2 For further evidence on positive effects of cognitive test scores on individual labor-market performance, see Rivera-Batiz (1992), Neal and Johnson (1996), Currie and Thomas (2001), and the references in the latter. Also at the international level, the average performance on cognitive achievement tests has a strong and consistent influence on economic growth, and their explanatory power in growth regressions is superior to that of mere quantitative measures of education (Hanushek and Kimko 2000; Barro 2001).

3 Cf. Wößmann (2004) for comparable European and US estimates of the "school production" part of education production functions, i.e. the effects of schools' resource endowments and institutional features of the school systems on students' educational performance.

4 Most existing studies on education production functions are restricted to individual countries. While most US studies include some control for family background, they tend to focus on resource effects with little direct focus on family-background effects (cf. Hanushek 2002, p. 2082). Of the few studies on educational production from European countries, exceptions discussing family-background effects include Ammermüller et al. (2003), Björklund et al. (2003), Brunello and Checchi (2003), Feinstein and Symons (1999), Fertig (2003), Häkkinen et al. (2003), Lindahl (2001), and Wolter and Vellacott (2003).
} 
(e.g., Bishop 1992). Results on science performance are presented in appendix tables. Section 3 presents the basic results on the impact of family background on student achievement in the 18 school systems. Section 4 compares the general pattern of the evidence between Europe and the United States. Section 5 extends the analysis to quantile regressions to investigate whether there is heterogeneity in the family-background effects across the conditional achievement distribution. Section 6 discusses whether the cross-country pattern of results suggests an equity-efficiency tradeoff in educational production. Section 7 summarizes the results and concludes on directions for future research.

\section{Data and Method}

This section discusses the TIMSS student performance database used in this paper, reports descriptive statistics for each country, and presents the empirical model to be estimated.

\subsection{The TIMSS Student Performance Data}

The Third International Mathematics and Science Study (TIMSS) is a large-scale crosscountry comparative test of student achievement, conducted in 1995 by the International Association for the Evaluation of Educational Achievement (IEA), an independent international cooperative of national research institutions and government agencies which has been developing and conducting cross-national studies of student achievement since 1959. ${ }^{5}$ From Western Europe, 17 separate school systems in 15 countries participated in TIMSS: Austria, Flemish and French Belgium, Denmark, England and Scotland, France, Germany, Greece, Iceland, Ireland, the Netherlands, Norway, Portugal, Spain, Sweden, and Switzerland. ${ }^{6}$ The TIMSS database combines individual student-level performance data in math and science with extensive information from background questionnaires for nationally representative samples of students in each of the countries.

In TIMSS, the target population of middle school students to which each participating country administered the test was defined as those students enrolled in the two adjacent

5 Comparable large-scale international student achievement tests are the repeat study of TIMSS in 1999, which included only five Western European countries, and the Programme for International Student Assessment (PISA), conducted in 2000 by the Organisation for Economic Co-operation and Development (OECD). The PISA target population of 15-year-old students might suffer from self-selection into the sample of students in some countries, while schooling is compulsory for the TIMSS target population of 13-year-olds in all countries considered in this paper.

6 Thus, among the bigger Western European countries, only Finland and Italy are missing in TIMSS. 
grades with the largest proportion of 13 -year-olds at the time of testing. ${ }^{7}$ TIMSS followed a curriculum-based test design, so that its questions are meant to reflect the students' current curriculum and are thus appropriate for them (cf. Martin and Kelly 1996; 1997). Thus, TIMSS covers the core material common to the curricula in the majority of participating countries, and every effort was made to help ensure that the items did not exhibit any bias towards or against particular countries. A matching analysis later performed between the test and the actual curriculum in each country showed that disregarding any items not covered in the country's intended curriculum barely affected the results.

Each participating country randomly sampled the schools to be tested in a stratified sampling design, and within each of these schools, generally one class was randomly chosen from each of the two grades and all of its students were tested in both math and science, yielding a representative sample of students within each country. ${ }^{8}$ Schools in geographically remote regions, extremely small schools, and schools for students with special needs were excluded from the target population. Within sampled schools, disabled students who were unable to follow even the test instructions were excluded; students who merely exhibited poor academic performance or discipline problems were required to participate (Martin and Kelly 1996). The overall exclusion rate was not to exceed $10 \%$ of the total student population. ${ }^{9}$

As a general rule, each country was meant to sample at least 150 schools (Gonzalez and Smith 1997). Response rates were not perfect (even after taking into account randomly selected replacement schools), though, while some countries sampled even more schools. ${ }^{10}$ As reported in Table 1, Switzerland features the largest sample size of the countries considered in this paper with 11,722 students in 613 classrooms in 327 schools, while England has the smallest number of sampled students at 3,579 and the Netherlands has the smallest number of sampled classrooms (187) and schools (95).

\footnotetext{
7 In most countries, this corresponded to $7^{\text {th }}$ and $8^{\text {th }}$ grade of formal education (excluding pre-primary education). Exceptions are Denmark, Norway, Sweden, and the German-speaking cantons of Switzerland, where tested students had 6/7 years of formal education, as well as England and Scotland with 8/9 years (Martin and Kelly 1997).

8 In Germany, one Bundesland (Baden-Württemberg) did not participate in TIMSS, and in Switzerland, four cantons did not participate. Denmark and Greece had unapproved sampling procedures at the classroom level (Beaton et al. 1996).

9 England was the only country not to meet this general rule with an overall exclusion rate of $11.3 \%$ because it excluded schools that were selected for specific national evaluation samples.

10 As a general guideline, TIMSS required participation rates of $85 \%$ or higher. This was not met by Austria, French Belgium, the Netherlands, and Scotland. Flemish Belgium, England, and Germany met the participation rates only after replacement schools were included, as did the United States (Beaton et al. 1996).
} 
TIMSS gave rigorous attention to quality control, using standardized procedures to ensure comparability in school and student sampling, to prevent bias, and to assure quality in test design and development, data collection, scoring procedures, and analysis. The TIMSS achievement tests were developed through an international consensus-building process involving inputs from international experts in math, science, and measurement, and were endorsed by all participating countries. Given the international standardization of the test results, the cooperative nature of the test development, its endorsement by all participating countries, and the substantial efforts to ensure high-quality sampling and testing in all countries, the TIMSS student performance and background data should be comparable across countries. This should also make the empirical estimates presented in this paper directly comparable across the different countries.

The performance data are merged with background data from TIMSS background questionnaires for each individual student. ${ }^{11}$ The information on student- and familybackground characteristics are mainly drawn from student background questionnaires, where students report the level of their parents' education, the number of books in their home, whether they live with both parents and were born in the country, and their sex and age. Additionally, school-principal background questionnaires provide information on the community location of the school. Except for student age, all background data are used as dummy variables in this paper.

Complete performance data are available for all the students participating in TIMSS. In terms of the background data, England did not administer the question on parental education in an internationally comparable way, and France on students' country of birth. Furthermore, some students and school principals failed to answer some items in the background questionnaires. While in general, response rates are reasonable, in some countries data on parental education and community location are missing for more than 40 percent of the students (cf. Table A1 in the appendix). In cases of missing data, the values were imputed within each country for the analyses in this paper. This seems superior to dropping all students with missing data on some explanatory variables altogether, because the latter would disregard the information available for these students on other explanatory variables, would severely reduce the sample size in several countries, and would probably introduce bias because it seems likely that observations are not missing at random. Appendix 1 presents the details of the method used to impute missing data, which uses both median imputation and

11 The background questionnaires are available at http://timss.bc.edu/timss1995i/database/UG1_Sup2.pdf. 
imputation based on probit models relating the observations from students with original data to a set of "fundamental" explanatory variables available for all students.

\subsection{Cross-Country Comparative Descriptive Statistics}

TIMSS measured student performance separately in math and science, using an international achievement scale with scores having an international mean of 500 and an international standard deviation of 100. As shown in Table 1, the mean math performance in TIMSS of the Western European countries ranges from 438.3 in Portugal to 561.7 in Flemish Belgium. As a comparison, Singapore was the international top performer at 622.3, South Africa was the lowest performer at 351, and the United States scored an average of 487.8 test-score points in math. The cross-country distribution of science performance in Western Europe is broadly comparable to the math performance, with the same top and low performers. Some countries still feature quite a difference in their performance across subjects, and the cross-country correlation of mean performance stands at 0.64 . Portugal has the lowest variation in math performance among its students, both when measured by the absolute standard deviation in test scores (63.7) and relative to its mean performance (14.5). On the relative measure, Flemish Belgium and France also feature relatively low performance variations. At the other extreme, England has the highest standard deviation in absolute terms (92.7), while in relative terms it is Greece (19.4). The United States also shows a relatively large performance variation among its students.

Table 2 presents country means of the data on family background used in this paper. The average parental education varies widely among the countries. On the one extreme, 57\% of Portuguese parents do not have any secondary education. On the other extreme, $40 \%$ of parents in French Belgium have a finished university education. Some of the cross-country variation in parental education levels may reflect differences in the education systems, though. The number of books in the students' home may be a proxy for the educational background of the family that is more readily comparable across countries. Portugal again fares relatively low on this measure, while Norway features relatively high values. The distribution across the five categories of books at home in countries such as England, Germany, and the United States is actually very similar.

Across Europe, the Netherlands had the lowest share of students not living with both parents at 9\%, while Scotland had the highest share at 19\%. The share was even higher in the United States at 21\%. The share of immigrant students ranges from 3\% in Flemish Belgium, Ireland, and Spain to $12 \%$ in Switzerland. In all countries, students are roughly equally 
divided into boys and girls. The average age of the tested students ranges from 13.1 years in Greece and Iceland to 14.3 years in Germany. ${ }^{12}$ In all countries, the student population is roughly equally divided between the two tested grades. Sweden and Switzerland tested students in a third grade above the other two, with roughly one third of their samples coming from each grade. In terms of the community in which the schools are located, Norway features a relatively high share of geographically isolated locations (12\%) and a relatively low share of schools located close to the center of a town (also 12\%). By contrast, several countries do not feature tested school in isolated areas, and 62\% of Portuguese students visit a school close to a town center.

\subsection{The Empirical Model}

To quantify the extent of equality of educational opportunities for children from different backgrounds, the size of the influence of students' family background on their educational performance is estimated for each country in the following form:

$$
T_{i c s}=F_{i c s} \alpha_{1}+D_{i c s}^{F} \delta_{1}+\left(D_{i c s}^{F} F_{i c s}\right) \delta_{2}+\varepsilon_{i c s}
$$

where $T$ is the test score of student $i$ in class $c$ in school $s$ and $F$ is a vector of familybackground variables. The coefficient vectors $\alpha_{1}, \delta_{1}$, and $\delta_{2}$ are to be estimated. The inclusion of the imputation controls $D^{F}$ and the structure of the error term $\varepsilon$ are discussed below.

Usually being determined before children are in school, family-background characteristics such as parental education can be viewed as exogenous to student performance. Furthermore, there is no self-selection into the sample because $7^{\text {th }}$ - and $8^{\text {th }}$-grade schooling is compulsory in Western Europe and the United States. Consequently, least-squares estimates of $\alpha_{1}$ should represent causal family-background effects. The estimation intentionally does not control for school characteristics, such as schools' resource endowments or institutional features, as in standard education production functions, because the paper is interested in the total impact of family background on student performance, including any effect that might work through families’ differential access to schools or their influence on school policies.

It should be noted that the estimated family-background effects combine the joint impact of nature and nurture, the relative importance of which cannot be distinguished in this dataset. Thus, the estimates of equality of educational opportunities may to some extent reflect the

12 Germany actually chose to test its $7^{\text {th }}$ and $8^{\text {th }}$ grade level to provide a decent curricular match, although that meant not testing the two grades with the most 13-year-olds. This breach of the official TIMSS age/grade specification led to German students being substantially older than those in most other countries. 
effect of heritable ability. ${ }^{13}$ However, the extent to which heritability can account for the cross-country variation in the findings should be limited.

It helps to clarify what the estimates of the coefficients $\alpha_{1}$ on the family-background variables, and especially differences in the estimates across countries, mean and do not mean. Because the TIMSS data were generated by the same data-generating process in the different countries and are therefore directly comparable across countries, and given the technical constraints on the pedagogical process, the prior should be that the size of the effect of any family-background characteristic on students' educational performance should be the same everywhere. If this is not the case, this implies that there must be differences in how the school systems work. This does not reflect different distributions of family-background characteristics in the different populations, as evident in Table 2, which are no a priori reason for the performance gap between students with two different characteristics to differ.

As discussed in the previous section, some of the data are imputed rather than original. Generally, data imputation introduces measurement error in the explanatory variables, which should make it more difficult to observe statistically significant effects. Still, to make sure that the results are not driven by imputed data, a vector of dummy variables $D^{F}$ is included as controls in the estimation. The vector $D^{F}$ contains one dummy for each variable in the familybackground vector $F$ that takes the value of 1 for observations with missing and thus imputed data and 0 for observations with original data. The inclusion of $D^{F}$ as controls in the estimation allows the observations with missing data on each variable to have their own intercepts. The inclusion of the interaction term between imputation dummies and background data, $D^{F} F$, allows them to also have their own slopes for the respective variable. These imputation controls for every variable with missing values ensure that the results are robust against possible bias arising from data imputation.

Further problems in the econometric estimation of equation (1) are that the explanatory variables in this study are measured at different levels, with some of them not varying within classes or schools; that the performance of students within the same school may not be independent from one another; and that the primary sampling unit (PSU) of the two-stage

\footnotetext{
13 More able parents, who obtained more education, may have more able children, who then perform better on the performance tests. Behrman and Rosenzweig (2002) show for Minnesota twins that heritable ability is a likely source of the correlation between the quantitative educational attainment of mothers and their children. This is not found for fathers, though, and Behrman et al. (1999) find a causal impact of mothers' schooling on their children's schooling, working through home teaching, in rural India during the green revolution. Similarly, Sacerdote (2002) and Plug and Vijverberg (2003) find somewhat contrary evidence on the relative importance of the nature and nurture components in the effect of parental background on children's educational outcomes.
} 
clustered sampling design in TIMSS was the school, not the individual student (see Section 2.1). As shown by Moulton (1986), a hierarchical structure of the data requires the addition of higher-level error components to avoid spurious results. Therefore, the error term $\varepsilon$ of equation (1) has a school-level and a class-level element in addition to the individual-student element:

$$
\varepsilon_{i c s}=\eta_{s}+v_{C}+v_{i}
$$

where $\eta$ is a school-specific error component, $v$ is a class-specific error component, and $v$ is a student-specific error component. Clustering-robust linear regression (CRLR) is used to estimate standard errors that recognize this clustering of the survey design. The CRLR method relaxes the independence assumption and requires only that the observations be independent across the PSUs, i.e. across schools. By allowing any given amount of correlation within the PSUs, CRLR estimates appropriate standard errors when many observations share the same value on some but not all independent variables (cf. Deaton 1997).

Finally, TIMSS used a stratified sampling design within each country, producing varying sampling probabilities for different students (Martin and Kelly 1997). To obtain nationally representative coefficient estimates from the stratified survey data, weighted least squares (WLS) estimation using the sampling probabilities as weights is employed. The WLS estimation ensures that the proportional contribution to the parameter estimates of each stratum in the sample is the same as would have been obtained in a complete census enumeration (DuMouchel and Duncan 1983; Wooldridge 2001).

\section{Results for Individual Countries}

This section presents results on the effect of several family-background features on students' educational performance in the United States and 17 Western European education systems. The size of the family-background effects can be viewed as a measure of the equality of educational opportunities for children from different backgrounds. The results, reported in Table 3, start with several measures of the educational background of the family, followed by student characteristics and the community location. Here as well as in the remaining sections, the discussion will focus on results for math performance. Results for science performance are quite similar and relegated to Tables A2-A3 in the appendix. 


\subsection{Families' Educational and Socio-Economic Background}

The education level attained by the parents is strongly related to student performance in all European countries, as well as the United States. The specification does not make the assumption of a linear relationship, e.g. by using parents' years of education as a single explanatory measure. Rather, the estimations use all the information available in the background questionnaires and allow a more flexible functional form by including a dummy for each category, namely parents whose highest education level is some secondary, finished secondary, some after secondary, and finished university, with parents with no secondary education at all as the residual category.

Across the European countries, the relationship between parents' education and their children's math performance is particularly low in French Belgium, the only country where the difference in math performance between students whose parents finished university and students whose parents had no secondary education is not statistically significant (although it is in science, cf. Table A2). At the other extreme, this difference is largest in Greece at 51.3 test-score points. The effect size is smaller in all Western European countries than the one observed in the United States (52.7), where basically all previous studies found important family-background effects (cf. Hanushek 2002). Effect sizes of 40-50 test-score points, as observed in of the countries, are very large indeed: They are of the same order of magnitude as the performance difference between $7^{\text {th }}$ and $8^{\text {th }}$ graders in most countries, and equal about half a standard deviation in TIMSS test scores (cf. Table 1). When considering the performance difference between children of parents who finished university and children of parents who finished secondary education, there is basically no difference in Spain, and the largest difference is observed in Scotland at 39.7 test-score points.

A limitation to the comparability of the effects of parental education across countries is that the categories in the different countries may not be easily comparable. Therefore, the second indicator of family background, the number of books in the students' home, may be particularly interesting for cross-country comparisons. Students were asked to report the total number of books that are in their home, not counting newspapers, magazines, or their school books. This measure can be viewed as a proxy of the educational, social, and economic background of the students' families that is readily comparable across countries. Again, this measure was collected in five categories. In the regressions reported in Table 3, England appears to feature the largest effect based on this measure. However, England is also the only country without data on parental education, which might affect the estimates on books at 
home. Therefore, the regressions were re-estimated without controlling for the parental education data also for all other countries to see whether the relative size of the coefficient on books at home in England can be attributed to the missing parental-education data. The coefficients on books at home actually do increase in all other countries once parental education is excluded.

However, England still has the largest effect among all countries, with students from homes with more than two bookcases full of books performing 104.4 math test-score points better than students from homes with less than one shelf of books. Scotland (93.6) and Germany (84.9) also feature very large family-background effects on this account, followed by Austria, Ireland, and Sweden. In all these countries, the effect of family background as measured by the number of books in a student's home on student performance is comparable to or larger than the effect found in the United States. At the other extreme, France features the lowest effect (20.9), and Flemish Belgium has the lowest effects when looked at relative to one shelf of books as the lowest category. A third country with relatively small effects is Portugal. This general pattern of results is basically unaffected by which specific difference one looks at; e.g. it also holds for two bookcases relative to less than one shelf, more than two bookcases relative to one shelf, more than two bookcases relative to one bookcase, or two bookcases relative to one shelf.

The relatively low intergenerational educational mobility in Britain mirrors previous findings of relatively low intergenerational earnings mobility in this country (cf. Dearden et al. 1997; Solon 2002). However, the Swedish results contrast with studies finding relatively high intergenerational earnings mobility in Sweden (cf. Björklund and Jäntti 1997; Solon 2002), suggesting that the latter is not predominantly driven by particularly strong equality in educational opportunities. This finding is in line with Björklund et al. (2004), who similarly show that the high intergenerational earnings mobility in Sweden in comparison to the United States does not seem to be related to the education system or to differences in the intergenerational transmission of quantities of education, but is almost exclusively driven by the lower earnings returns to education in Sweden.

Two neighboring countries of which one belongs to the group of countries with small family-background impacts and the other to the group with large family-background impacts are France and Germany. In a French-German comparison of the impact of family background on educational attainment, Lauer (2003) hypothesizes that family background should have a larger impact on children's educational prospects in Germany than in France, 
mainly based on the observation that streaming takes place much earlier in the German school system than in the French one (cf. also Schnepf 2002). However, her evidence suggests that the two countries prove surprisingly similar with regard to the impact of family background on educational attainment, i.e. on a measure of educational quantity. By contrast, my results show that when using a measure of educational quality instead, her hypothesis actually holds true. That is, the larger family-background effect in Germany materializes in terms of better educational performance of the children rather than higher educational attainment. One way to reconcile the two findings would be that certification regimes differ, so that the attainment certificates represent different ranges of actual skills in the two countries.

The extent to which the differing finding with regard to performance is due to the different streaming practices in the two systems is an open question, though, because the two systems also differ in several other important dimensions. Most notably, France features a much more widespread prevalence of pre-primary education than Germany. Starting at the age of 3, more than $90 \%$ of children are enrolled in the French education system, while in Germany, this is not the case until the age of 7 (data for 1996 from OECD 1998). Of the children aged 2-4, 80\% are enrolled in France but only $45 \%$ in Germany. This may be another impact factor lying behind the large French-German difference in family-background effects, and it could also account for the low family-background effect in Flemish Belgium where the 90\% enrollment range also starts at the age of 3 and where $79 \%$ of children aged 2-4 are enrolled.

In interpreting the results, one has to bear in mind that family-background measures such as parental education or the number of books at home will be correlated with other, unobserved aspects of family background, such as parents' motivation or their willingness and capability to help with homework. Therefore, the estimated coefficients have to be interpreted as the effect of the respective variable and anything else that goes with it. In that sense, both parental education and the number of books at home serve as general proxies for the educational, social and economic background in the students' homes.

\subsection{Single Parents, Immigrants, Other Student Characteristics, and Community Location}

The next measure of family background is whether students live with both parents. In no country do students living with both parents perform statistically significantly worse than students not living with both parents, and they perform statistically significantly better in the United States and 8 Western European school systems. Only in Norway (18.7) is the effect larger than in the United States (15.5), and the next-largest effects are in Ireland, Greece, and Germany. 
The other considered student characteristics are also significantly related to student performance in many of the countries. Native students perform statistically significantly better than immigrated students in 10 European countries, but not in the United States (at least in math). The estimated effect is largest in Sweden (30.3), followed by Austria (25.9), Switzerland, Norway, and Denmark. By contrast, immigrated students actually perform statistically significantly (at least at the 5\% level) better than native students in Ireland (13.2) and Portugal (6.1). ${ }^{14}$

With regard to students' gender, Flemish Belgium, Iceland, and Sweden are the only countries where girls do not perform statistically significantly worse in math than boys. The boys' lead is largest by far in Ireland (19.7), followed by Switzerland (13.3), French Belgium (13.1), and Denmark (12.6).

Controlling for grade differences, older students perform statistically significantly worse in most countries, which presumably reflects a grade repetition effect. In all countries, $8^{\text {th }}$ graders perform statistically significantly higher than $7^{\text {th }}$-graders. The performance difference ranges from 23.0 in England to 67.4 in France. In countries with small performance differences between grades (e.g., England, Iceland, Scotland, and to a lesser extent Norway and Sweden), the age effect tends to be low (in absolute terms), while it tends to be high in countries with strongly negative age effects (e.g., France, the Netherlands, and the two Belgian systems). This may reflect differences in the policies of how to deal with lowperforming students. In the latter countries, the lowest-performing students regularly seem to be relegated into lower grades, so that the grade difference is relatively large, and at the same time the age effect is strongly negative since the relegated students are older but relatively low performing. By contrast, in the former countries, low-performing students generally seem not to be relegated to lower grades, so that the performance difference between grades is relatively low as the low-performers remain in upper grade, and age does not make much of a difference within grades and might even have a slightly positive effect on performance.

Finally, there is no clear pattern in the relative performance of schools by community location. In some countries, schools in geographically isolated locations perform much worse, while in others, they perform much better. Here, it should also be noted that most of the statistically significant estimates are based on very few observations, because only 2 schools

\footnotetext{
14 Because the strong correlation between the immigration status of parents and children regularly causes problems of multicollinearity, only the latter was included in the regressions and the former left out, with the evident ensuing consequences for the interpretation of results.
} 
in Austria and Portugal, and only 1 in Spain, are reported to be geographically isolated (cf. Table 2). There is also no clear pattern of results for schools located in communities close to the center of a town.

The explanatory power of the student and family background characteristics, when measured as the proportion of the test-score variation accounted for by the model (the $R^{2}$ ), is largest in Switzerland at 26.4\% (disregarding the part "explained" by imputation controls), followed by French Belgium, Sweden, and France. At the lower end, 9.2\% of the performance variation can be attributed to family background in Iceland, followed by Denmark, Norway, and Flemish Belgium. In the United States, it is $17.5 \%$.

\section{Equality of Educational Opportunity in Europe vs. the United States: The Aggregate Picture}

The previous discussion already allowed a comparison of results for European countries with the United States at an individual-country level. To estimate more formally how the equality of educational opportunity compares between the United States and Europe as an aggregate, Table 4 reports the same model specification used above in Table 3 for the pooled sample of all students from the European countries and the United States. For each explanatory variable, the pooled regression includes an interaction term with a Europe dummy to test whether the family-background effect differs between Europe and the United States. The regression also controls for a whole set of country dummies to account for country fixed effects.

Comparing Europe as an aggregate to the United States, there is remarkably little difference in the direction, size, and significance of the family-background effects. Particularly when considering parental education and books at home as the main measures of family background, their effects on student performance in math actually barely differ between the "average” European country and the United States. At low levels of significance, there are slight differences in the size of the performance difference between the lowest two categories, and the effect of parents having finished university is somewhat larger in the United States. As a general pattern, however, family background has a strong and comparable impact on student performance both in Europe and the United States.

The effect of students living with both parents is statistically significantly smaller in Europe than in the United States, but it is still statistically significantly positive. Europe differs from the United States in that immigrant students perform statistically significantly worse than native students in math, which is not the case in the United States. There is also a 
difference in that students from schools located in geographically isolated areas perform statistically significantly worse in the United States, but not in Europe. However, the effects of students' age, gender, grade, and town-center location of schools do not differ significantly between Europe and the United States. All in all, when taking Western Europe as a whole, there is remarkably little difference in family-background effects to the United States, not even in their size.

\section{Heterogeneity of Family-Background Effects by Ability}

Given that $75-90 \%$ of the test-score variation in the different countries remains unexplained, a large part of the performance variation across students has to be attributed to omitted variables (in addition to measurement errors and random variation). This is not unexpected, because the basic learning ability of students - e.g., their innate ability or their learning motivation - remains unobserved and thus enters the error term $\varepsilon$ of equation (1) (or, more precisely, the student-specific error component $v$ in equation (2)). However, it begs the question whether the family-background effects vary across the ability distribution of students. E.g., it may be of different importance to low-ability students compared to highability students whether they come from a disadvantaged family background. Such heterogeneity in the family-background effects can be detected by quantile regressions (cf. Koenker and Bassett 1978).

Student ability itself remains unmeasured, virtually by definition. However, once familybackground effects are controlled for, the conditional performance distribution should be strongly correlated with ability (or, more precisely, with that part of ability that is not correlated with family background). In the following, this conditional performance distribution is termed “ability.” Quantile regressions estimate the effect of family background on student performance for students at different points on this ability distribution. While Eide and Showalter (1998) and Levin (2001) have applied the quantile regression method to the estimation of resource effects in education, Fertig (2003) seems to be the only country study that uses quantile regressions to estimate family-background effects. However, the distinction between family background and underlying ability seems to offer a particularly appealing analytical background for the estimation and interpretation of quantile estimates. The familybackground proxy used in this section is the number of books at home, which has the advantage over parental education to be readily comparable across countries and whose effect is considerably stronger than that of any other variable. 
The horizontal lines of Figure 1 replicate the least-squares coefficients on the four booksat-home dummies from Table 3 for each country. The relatively large effects in England and the relatively small effects in France are immediately apparent. The curved lines with dots report quantile-regression coefficients of the same model for 19 quantiles ranging from 0.05 to $0.95 .{ }^{15}$ As a general pattern, these quantile-regression estimates are relatively constant across quantiles in almost all countries. This remarkable uniformity suggests that the familybackground effects do not vary strongly with the underlying ability of students.

To the extent that they do, they tend to increase with quantiles in the vast majority of countries. This pattern of family-background effects slightly increasing with ability is particularly notable in Austria, England, Ireland, Norway, Spain, Sweden, and the United States. To a lesser extent, it may also be observed in French Belgium, France, Germany, Greece, Iceland, Portugal, Scotland, and Switzerland. However, England is the only country where a strong pattern of effect heterogeneity exists. ${ }^{16}$ In all these countries - albeit to varying degrees - a good family background is most important for high-ability children. Thus, for instance, while the performance lead of students from homes with more than two bookcases over students from homes with less than one shelf of books is 69.4 for students at the $10^{\text {th }}$ percentile of the conditional performance distribution in England, it is 146.5 for students at the $90^{\text {th }}$ percentile. This effect difference of 77.1 between the $10^{\text {th }}$ and the $90^{\text {th }}$ percentile in England compares, e.g., to a difference of only 5.3 in Switzerland (59.1 at the $90^{\text {th }}$ percentile versus 53.7 at the $10^{\text {th }}$ percentile). In the countries where no increasing pattern can be observed, the family-background effect seems to slightly shrink with ability in the Netherlands, be roughly U-shaped in Flemish Belgium, and inverted-U-shaped in Denmark.

The median regression can also be viewed as a test of the least-squares result for robustness against outliers. The conditional median function estimated by median regression minimizes the sum of the absolute residuals and is thus less prone to outliers than the conditional mean function estimated by least-squares regressions. In this sense, median regressions may better describe the central tendency of the data. As is evident from Figure 1,

\footnotetext{
15 Confidence intervals are not shown for expositional reasons. For the least-squares estimates, standard errors are reported in Table 3. The precision of the quantile-regression coefficients is roughly comparable in size.

16 One might advance the thought that conditional performance may reflect other, unmeasured familybackground characteristics as much as underlying ability. At a first glance, this would suit to the fact that England is the only country with a strong positive link between family-background effects and underlying ability and that it is also the only country with no data available to control for parental education as a second family-background measure. However, performing the same quantile regressions under negligence of the parental education variables for the other countries reveals that this is not driving the exceptional English result.
} 
in most countries the least-squares and the median estimates do roughly coincide. In these countries, the initial least-squares results do not seem to be substantially biased by outlying observations. A difference between the two estimates in some countries suggests that the least-squares estimates seem to be affected to an extent by outliers. In Flemish Belgium, the median estimates are somewhat smaller than the least-squares estimates, suggesting that outliers seem to affect the least-squares coefficients in an upward direction. By contrast, in Austria, Denmark, and Norway, the median estimates are slightly larger than the least-squares estimates, suggesting that outliers seem to affect the least-squares coefficients in a downward direction.

\section{Is There a Tradeoff Between Equality and Efficiency?}

Viewing the size of the family-background effects as a measure of the equality of educational opportunities for children from different backgrounds, the French school system seems to achieve the highest extent of equal opportunity, and the British systems the lowest. From a policy viewpoint, this begs the question whether equalizing educational opportunities must be bought by having to accept a lower overall level of performance, i.e. whether a tradeoff exists between educational equity and efficiency.

To give a cross-country view on this question, Figure 2 plots the mean of the math achievement in each country against a measure of the family-background effect in the country, namely the performance difference between students with more than two bookcases at home and students with less than one shelf of books at home. From this scatter plot, it is evident that there is no direct relationship between average performance and the measure of equality of opportunity across countries. The cross-country correlation coefficient between the two measures is 0.002 .

When using other proxies for family-background effects, the correlation with mean performance is similarly low, and often negative. For example, the correlation coefficient is -0.03 for the performance difference between students with more than two bookcases relative to students with one shelf as the proxy for family-background effects, -0.15 for more than two bookcases relative to one bookcase, and 0.11 for two bookcases relative to less than one shelf as well as one shelf. Likewise, using parental education as the family-background proxy, the correlation coefficient with mean math performance is -0.11 when considering the

performance difference between students whose parents finished university relative to 
students whose parents had no secondary education, and -0.10 when considering finished university relative to finished secondary.

Thus, the cross-country pattern of mean performance and family-background effects suggests that there is no obvious tradeoff between achieving efficiency in educational production and equality of educational opportunity. While being illustrative, this crosscountry snapshot can give only a first descriptive impression, requiring much more in-depth analysis before any definite conclusion seems warranted.

\section{Summary and Conclusions}

This paper has presented consistent and comparable evidence on how equal educational opportunities are for children from different family backgrounds in Western European countries and the United States. The evidence is based on the estimated size of the impact that several measures of family background have on students' performance on the TIMSS international achievement test in lower secondary education. In all countries, the impact of family background on students' cognitive skills is strong. For example, the performance difference between children of parents with the lowest and the highest educational category easily surmount a whole grade equivalent in many countries. Furthermore, the model analyzed in this paper is able to account for at least $9 \%$ of the total test-score variation (in Iceland), and up to $26.4 \%$ (in Switzerland). Both the size of the individual effects and the explained proportion of the test-score variation dwarf the effects that have been found for school inputs such as class sizes, teacher characteristics, resource endowments, and institutional features for the same countries and performance data (Wößmann 2004).

With regard to the general pattern of strong family-background effects, and even with regard to the particular size of most family-background effects, equality of educational opportunities in Western Europe (as an aggregate) seems remarkably similar to the United States. Still, there are also noteworthy variations across European countries. Using the number of books in the students' home as a proxy for the educational and socio-economic background of the family, France and Flemish Belgium achieve the most equitable performance for students from different backgrounds, and Britain and Germany the least. In most countries, family-background effects do not vary strongly for students of different underlying ability. If anything, the effects tend to be stronger for higher-ability children in some countries, most notably in England. Across countries, the size of the family-background effects is basically unrelated to mean performance, suggesting that there is no inevitable 
equity-efficiency tradeoff in educational production. More equal opportunities for students from different family backgrounds thus do not necessarily have to be bought by lower average performance.

The findings in this paper open the door for much more in-depth future research. For example, the paper has not looked into how family-background effects work through different channels - through peer formation, differential access to resources, or other impacts on school policies. Likewise, there might be important interactions between the family-background effects themselves, for example between parental education and immigration status. Other international datasets such as the TIMSS-Repeat and the PISA studies may offer additional evidence, despite their drawbacks for the particular question analyzed in this paper (focusing on Western European countries in addition to the United States and looking at an age where the whole cohort is still in school). Furthermore, the international primary-school study PIRLS may yield evidence to better understand at which stage equality of opportunities are gained or lost in the different countries. Also, while this paper has focused mainly on basic cognitive skills in math as an educational output, only briefly reporting results in science, there are many other outcomes of the educational process that should be considered in the future, such as social capabilities and motivation.

The results of this paper are generally in line with the broad pattern of the existing crosscountry evidence on intergenerational earnings mobility, which found that the United States and the United Kingdom appear to be relatively immobile societies (Solon 2002). The evidence on intergenerational educational mobility presented here extends this pattern to a much wider range of countries. The understanding of how educational and earnings mobility relate and how the one transforms into the other might be greatly advanced if familybackground and student-achievement data could be directly linked to data on labor-market outcomes in different generations.

The most auspicious and proximate road for future research, however, seems to be to look at what might lie behind the cross-country differences in the extent of equality of educational opportunities estimated in this paper. The results can feed future work trying to explain why some countries achieve more educational equality than others, by relating the estimated family-background effects to characteristic features of the school systems and societal institutions across countries. Such research might advance our understanding of how more equal educational opportunities might be achieved. 


\section{References}

Altonji, Joseph G., Charles R. Pierret (2001). Employer Learning and Statistical Discrimination. Quarterly Journal of Economics 116 (1): 313-350.

Ammermüller, Andreas, Hans Heijke, Ludger Wößmann (2003). Schooling Quality in Eastern Europe: Educational Production During Transition. Research Memorandum ROA-RM2003/2E. Maastricht: Research Centre for Education and the Labour Market.

Ashenfelter, Orley, Colm Harmon, Hessel Oosterbeek (1999). A Review of Estimates of the Schooling/Earnings Relationship, with Tests for Publication Bias. Labour Economics 6 (4): 453-470.

Barro, Robert J. (2001). Human Capital and Growth. American Economic Review, Papers and Proceedings 91 (2): 12-17.

Beaton, Albert E., Ina V.S. Mullis, Michael O. Martin, Eugenio J. Gonzalez, Dana L. Kelly, Teresa A. Smith (1996). Mathematics Achievement in the Middle School Years: IEA's Third International Mathematics and Science Study (TIMSS). Chestnut Hill, MA: Boston College.

Behrman, Jere R., Andrew D. Foster, Mark R. Rosenzweig, Prem Vashishtha (1999). Women's Schooling, Home Teaching, and Economic Growth. Journal of Political Economy 107 (4): 682-714.

Behrman, Jere R., Mark R. Rosenzweig (2002). Does Increasing Women's Schooling Raise the Schooling of the Next Generation? American Economic Review 92 (1): 323-334.

Bishop, John H. (1989). Is the Test Score Decline Responsible for the Productivity Growth Decline? American Economic Review 79 (1): 178-197.

Bishop, John H. (1992). The Impact of Academic Competencies on Wages, Unemployment, and Job Performance. Carnegie-Rochester Conference Series on Public Policy 37: 127194.

Björklund, Anders, Per-Anders Edin, Peter Freriksson, Alan Krueger (2004). Education, Equality and Efficiency: An Analysis of Swedish School Reforms during the 1990s. IFAU Report 2004:1. Uppsala: Institute for Labour Market Policy Evaluation.

Björklund, Anders, Markus Jäntti (1997). Intergenerational Income Mobility in Sweden Compared to the United States. American Economic Review 87 (5): 1009-1018.

Björklund, Anders, Mikael Lindahl, Krister Sund (2003). Family Background and School Performance During a Turbulent Era of School Reforms. Swedish Economic Policy Review 10 (2): 111-136.

Boissiere, M., J.B. Knight, R.H. Sabot (1985). Earnings, Schooling, Ability, and Cognitive Skills. American Economic Review 73 (5): 1016-1030.

Brunello, Giorgio, Daniele Checchi (2003). School Quality and Family Background in Italy. IZA Discussion Paper 705. Bonn: Institute for the Study of Labor.

Card, David (1999). The Causal Effect of Education on Earnings. In: Orley Ashenfelter, David Card (eds.), Handbook of Labor Economics, Volume 3A: 1801-1863. Amsterdam: Elsevier.

Currie, Janet, Duncan Thomas (2001). Early Test Scores, School Quality and SES: Longrun Effects on Wage and Employment Outcomes. Research in Labor Economics 20: 103-132. 
Deaton, Angus (1997). The Analysis of Household Surveys: A Microeconometric Approach to Development Policy. Baltimore: The Johns Hopkins University Press.

Dearden, Lorraine, Stephen Machin, Howard Reed (1997). Intergenerational Mobility in Britain. Economic Journal 107 (1): 47-66.

DuMouchel, William H., Greg J. Duncan (1983). Using Sample Survey Weights in Multiple Regression Analyses of Stratified Samples. Journal of the American Statistical Association 78 (383): 535-543.

Eide, Eric, Mark H. Showalter (1998). The Effect of School Quality on Student Performance: A Quantile Regression Approach. Economics Letters 58 (3): 345-350.

Ermisch, John, Marco Francesconi (2001). Family Matters: Impacts of Family Background on Educational Attainments. Economica 68 (270): 137-156.

Feinstein, Leon, James Symons (1999). Attainment in Secondary School. Oxford Economic Papers 51 (2): 300-321.

Fertig, Michael (2003). Who's to Blame? The Determinants of German Students' Achievement in the PISA 2000 Study. IZA Discussion Paper 739. Bonn: Institute for the Study of Labor.

Gonzalez, Eugenio J., Teresa A. Smith (eds.) (1997). User Guide for the TIMSS International Database: Primary and Middle School Years. Chestnut Hill, MA: Boston College.

Häkkinen, Iida, Tanja Kirjavainen, Roope Uusitalo (2003). School Resources and Student Achievement Revisited: New Evidence from Panel Data. Economics of Education Review 22 (3): 329-335.

Hanushek, Eric A. (2002). Publicly Provided Education. In: Alan J. Auerbach, Martin Feldstein (eds.), Handbook of Public Economics, Volume 4: 2045-2141. Amsterdam: Elsevier.

Hanushek, Eric A., Dennis D. Kimko (2000). Schooling, Labor-Force Quality, and the Growth of Nations. American Economic Review 90 (5): 1184-1208.

Koenker, Roger, Gilbert Bassett, Jr. (1978). Regression Quantiles. Econometrica 46 (1): 3350 .

Lauer, Charlotte (2003). Family Background, Cohort and Education: A French-German Comparison Based on a Multivariate Ordered Probit Model of Educational Attainment. Labour Economics 10 (2): 231-251.

Levin, Jesse (2001). For Whom the Reductions Count: A Quantile Regression Analysis of Class Size and Peer Effects on Scholastic Achievement. Empirical Economics 26 (1): 221246.

Lindahl, Mikael (2001). Summer Learning and the Effect of Schooling: Evidence from Sweden. IZA Discussion Paper 262. Bonn: Institute for the Study of Labor.

Martin, Michael O., Dana L. Kelly (eds.) (1996). Third International Mathematics and Science Study Technical Report, Volume I: Design and Development. Chestnut Hill, MA: Boston College.

Martin, Michael O., Dana L. Kelly (eds.) (1997). Third International Mathematics and Science Study Technical Report, Volume II: Implementation and Analysis - Primary and Middle School Years. Chestnut Hill, MA: Boston College.

Moulton, Brent R. (1986). Random Group Effects and the Precision of Regression Estimates. Journal of Econometrics 32 (3): 385-397. 
Murnane, Richard J., John B. Willett, Frank Levy (1995). The Growing Importance of Cognitive Skills in Wage Determination. Review of Economics and Statistics 77 (2): 251266.

Neal, Derek A., William R. Johnson (1996). The Role of Premarket Forces in Black-White Wage Differences. Journal of Political Economy 104 (5): 869-895.

Organisation for Economic Co-operation and Development (OECD) (1998). Education at a Glance: OECD Indicators. Paris: OECD.

Plug, Erik, Wim Vijverberg (2003). Schooling, Family Background, and Adoption: Is It Nature or Is It Nurture? Journal of Political Economy 111 (3): 611-641.

Rivera-Batiz, Francisco L. (1992). Quantitative Literacy and the Likelihood of Employment Among Young Adults in the United States. Journal of Human Resources 27 (2): 313-328.

Roemer, John E. (1998). Equality of Opportunity. Cambridge, MA: Harvard University Press.

Sacerdote, Bruce (2002). The Nature and Nurture of Economic Outcomes. American Economic Review, Papers and Proceedings 92 (2): 344-348.

Schnepf, Sylke Viola (2002). A Sorting Hat That Fails? The Transition from Primary to Secondary School in Germany. Innocenti Working Papers 92. Florence: UNICEF Innocenti Research Centre.

Solon, Gary (1999). Intergenerational Mobility in the Labor Market. In: Orley Ashenfelter, David Card (eds.), Handbook of Labor Economics, Volume 3A: 1761-1800. Amsterdam: Elsevier.

Solon, Gary (2002). Cross-Country Differences in Intergenerational Earnings Mobility. Journal of Economic Perspectives 16 (3): 59-66.

Tyler, John H., Richard J. Murnane, John B. Willett (2000). Do the Cognitive Skills of School Dropouts Matter in the Labor Market? Journal of Human Resources 35 (4): 748-754.

Wolter, Stefan C., Maja Coradi Vellacott (2003). Sibling Rivalry for Parental Resources: A Problem for Equity in Education? A Six-Country Comparison with PISA Data. Swiss Journal of Sociology: forthcoming. (Available as: IZA Discussion Paper 734. Bonn: Institute for the Study of Labor.)

Wooldridge, Jeffrey M. (2001). Asymptotic Properties of Weighted M-Estimators for Standard Stratified Samples. Econometric Theory 17 (2): 451-470.

Wößmann, Ludger (2004). Educational Production in Europe. Preliminary Version of a Paper Prepared for the $40^{\text {th }}$ Panel Meeting of Economic Policy in Amsterdam. Mimeo, ifo Institute for Economic Research at the University of Munich. 
Table 1: Student Performance and Sample Size

Student performance: Mean of international test scores. Standard deviation in parentheses. Standard deviation in percent of country mean test score in brackets. - Sample size: Absolute numbers.

\begin{tabular}{lrrrrrrrrr}
\hline \hline & AUS & BFL & BFR & DEN & ENG & FRA & GER & GRE & ICE \\
\hline \hline Student performance & & & & & & & & & \\
$\quad$ Math score & 524.1 & 561.7 & 517.5 & 485.3 & 491.3 & 514.4 & 496.6 & 461.2 & 473.1 \\
$\quad$ Standard deviation & $(89.9)$ & $(85.3)$ & $(83.1)$ & $(83.1)$ & $(92.7)$ & $(78.3)$ & $(88.2)$ & $(89.6)$ & $(73.3)$ \\
$\quad$ Std. dev./score (in percent) & {$[17.2]$} & {$[15.2]$} & {$[16.1]$} & {$[17.1]$} & {$[18.9]$} & {$[15.2]$} & {$[17.8]$} & {$[19.4]$} & {$[15.5]$} \\
Science score & 537.9 & 540.3 & 457.5 & 460.5 & 532.5 & 473.9 & 515.2 & 472.2 & 477.8 \\
$\quad$ Standard deviation & $(98.0)$ & $(78.3)$ & $(83.7)$ & $(89.4)$ & $(105.5)$ & $(78.9)$ & $(99.8)$ & $(89.6)$ & $(78.7)$ \\
$\quad$ Std. dev./score (in percent) & {$[18.2]$} & {$[14.5]$} & {$[18.3]$} & {$[19.4]$} & {$[19.8]$} & {$[16.7]$} & {$[19.4]$} & {$[19.0]$} & {$[16.5]$} \\
\hline Sample size & & & & & & & & \\
$\quad$ Students & 5,786 & 5,662 & 4,883 & 4,370 & 3,579 & 6,014 & 5,763 & 7,921 & 3,730 \\
Classes & 249 & 296 & 261 & 282 & 243 & 253 & 272 & 312 & 274 \\
$\quad$ Schools & 129 & 141 & 120 & 153 & 127 & 134 & 137 & 156 & 155 \\
\hline \hline
\end{tabular}

Table 1 (continued)

\begin{tabular}{|c|c|c|c|c|c|c|c|c|c|}
\hline & IRE & NET & NOR & POR & SCO & SPA & SWE & SWI & USA \\
\hline \multicolumn{10}{|l|}{ 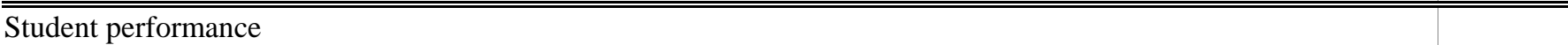 } \\
\hline Math score & 513.5 & 529.0 & 481.8 & 438.3 & 481.1 & 467.6 & 517.1 & 544.6 & 487.8 \\
\hline Standard deviation & $(90.8)$ & $(85.2)$ & (82.8) & $(63.7)$ & $(86.5)$ & $(74.2)$ & $(90.2)$ & $(91.2)$ & (90.9) \\
\hline Std. dev./score (in percent) & [17.7] & [16.1] & [17.2] & [14.5] & [18.0] & [15.9] & [17.5] & [16.8] & [18.6] \\
\hline Science score & 516.4 & 539.6 & 505.0 & 452.9 & 493.2 & 497.1 & 532.0 & 521.0 & 521.4 \\
\hline Standard deviation & $(95.7)$ & $(85.0)$ & (88.9) & $(77.1)$ & (99.9) & $(81.4)$ & $(95.7)$ & (93.9) & (106.2) \\
\hline Std. dev./score (in percent) & [18.5] & [15.7] & [17.6] & [17.0] & [20.3] & [16.4] & [18.0] & [18.0] & [20.4] \\
\hline \multicolumn{10}{|l|}{ Sample size } \\
\hline Students & 6,203 & 4,084 & 5,736 & 6,753 & 5,776 & 7,596 & 8,855 & 11,722 & 10,973 \\
\hline Classes & 261 & 187 & 287 & 283 & 257 & 309 & 535 & 613 & 529 \\
\hline Schools & 132 & 95 & 249 & 142 & 128 & 154 & 270 & 327 & 183 \\
\hline
\end{tabular}




\section{Table 2: Descriptive Family-Background Statistics}

Country means. Standard deviations in parentheses for continuous variable (std. dev. for dummies equal roughly $2 *$ mean*(1-mean), neglecting the weighting). Only non-imputed data for each variable. Weighted by sampling probabilities.

\begin{tabular}{|c|c|c|c|c|c|c|c|c|c|}
\hline & AUS & $\mathrm{BFL}$ & BFR & DEN & ENG & FRA & GER & GRE & ICE \\
\hline \multicolumn{10}{|l|}{ Parents' education } \\
\hline Primary & - & 0.08 & 0.06 & - & - & 0.09 & - & 0.23 & 0.08 \\
\hline Some secondary & 0.10 & 0.18 & 0.09 & 0.11 & - & 0.25 & 0.47 & 0.18 & 0.09 \\
\hline Finished secondary & 0.78 & 0.40 & 0.20 & 0.35 & - & 0.33 & 0.34 & 0.17 & 0.12 \\
\hline Some after secondary & - & 0.06 & 0.25 & 0.33 & - & 0.15 & 0.06 & 0.22 & 0.39 \\
\hline Finished university & 0.13 & 0.29 & 0.40 & 0.21 & - & 0.18 & 0.14 & 0.20 & 0.32 \\
\hline \multicolumn{10}{|l|}{ Books at home } \\
\hline Less than one shelf $(<=10)$ & 0.11 & 0.09 & 0.06 & 0.03 & 0.06 & 0.05 & 0.08 & 0.05 & 0.01 \\
\hline One shelf (11-25) & 0.16 & 0.16 & 0.10 & 0.09 & 0.13 & 0.19 & 0.14 & 0.23 & 0.05 \\
\hline One bookcase (26-100) & 0.32 & 0.34 & 0.29 & 0.29 & 0.27 & 0.36 & 0.28 & 0.41 & 0.30 \\
\hline Two bookcases (101-200) & 0.18 & 0.19 & 0.21 & 0.23 & 0.23 & 0.20 & 0.19 & 0.19 & 0.28 \\
\hline More than two bookcases $(>200)$ & 0.24 & 0.22 & 0.35 & 0.36 & 0.32 & 0.20 & 0.32 & 0.12 & 0.36 \\
\hline Living with both parents & 0.85 & 0.90 & 0.85 & 0.86 & 0.83 & 0.86 & 0.83 & 0.84 & 0.84 \\
\hline Born in country & 0.94 & 0.97 & 0.91 & 0.94 & 0.95 & - & 0.90 & 0.94 & 0.93 \\
\hline Sex (female) & 0.52 & 0.50 & 0.52 & 0.51 & 0.47 & 0.50 & 0.51 & 0.48 & 0.49 \\
\hline \multirow[t]{2}{*}{ Age } & 13.81 & 13.64 & 13.79 & 13.43 & 13.57 & 13.81 & 14.27 & 13.12 & 13.14 \\
\hline & $(0.71)$ & $(0.76)$ & $(0.91)$ & $(0.64)$ & $(0.58)$ & $(0.91)$ & $(0.82)$ & $(0.74)$ & $(0.58)$ \\
\hline Upper grade & 0.49 & 0.54 & 0.54 & 0.55 & 0.51 & 0.49 & 0.49 & 0.48 & 0.50 \\
\hline Above upper grade & - & - & - & - & - & - & - & - & - \\
\hline \multicolumn{10}{|l|}{ Community location } \\
\hline Geographically isolated & 0.00 & 0.00 & 0.00 & 0.07 & 0.04 & 0.00 & 0.02 & 0.03 & 0.07 \\
\hline Close to town center & 0.43 & 0.39 & 0.56 & 0.23 & 0.33 & 0.39 & 0.48 & 0.52 & 0.42 \\
\hline
\end{tabular}

Table 2 (continued)

\begin{tabular}{|c|c|c|c|c|c|c|c|c|c|}
\hline & IRE & NET & NOR & POR & $\mathrm{SCO}$ & SPA & SWE & SWI & USA \\
\hline \multicolumn{10}{|l|}{ Parents' education } \\
\hline Primary & 0.07 & 0.04 & - & 0.57 & _- & 0.43 & - & _- & 0.02 \\
\hline Some secondary & 0.21 & 0.09 & 0.12 & 0.21 & 0.23 & 0.16 & 0.14 & 0.15 & 0.06 \\
\hline Finished secondary & 0.30 & 0.31 & 0.12 & 0.09 & 0.36 & 0.10 & 0.44 & 0.61 & 0.19 \\
\hline Some after secondary & 0.23 & 0.39 & 0.40 & 0.05 & 0.18 & 0.12 & 0.10 & 0.11 & 0.38 \\
\hline Finished university & 0.19 & 0.18 & 0.36 & 0.09 & 0.23 & 0.19 & 0.32 & 0.13 & 0.36 \\
\hline \multicolumn{10}{|l|}{ Books at home } \\
\hline Less than one shelf $(<=10)$ & 0.07 & 0.07 & 0.02 & 0.12 & 0.11 & 0.05 & 0.03 & 0.07 & 0.08 \\
\hline One shelf (11-25) & 0.16 & 0.15 & 0.06 & 0.27 & 0.17 & 0.18 & 0.08 & 0.15 & 0.12 \\
\hline One bookcase (26-100) & 0.34 & 0.34 & 0.25 & 0.31 & 0.29 & 0.33 & 0.24 & 0.31 & 0.28 \\
\hline Two bookcases (101-200) & 0.21 & 0.20 & 0.23 & 0.13 & 0.19 & 0.19 & 0.24 & 0.21 & 0.21 \\
\hline More than two bookcase & 0.22 & 0.24 & 0.44 & 0.17 & 0.25 & 0.25 & 0.41 & 0.27 & 0.31 \\
\hline Living with both parents & 0.90 & 0.91 & 0.85 & 0.88 & 0.81 & 0.89 & 0.86 & 0.84 & 0.79 \\
\hline Born in country & 0.97 & 0.95 & 0.95 & 0.92 & 0.92 & 0.97 & 0.92 & 0.88 & 0.93 \\
\hline Sex (female) & 0.52 & 0.50 & 0.50 & 0.50 & 0.49 & 0.50 & 0.49 & 0.50 & 0.50 \\
\hline \multirow[t]{2}{*}{ Age } & 13.93 & 13.82 & 13.37 & 13.97 & 13.22 & 13.76 & 13.94 & 14.07 & 13.74 \\
\hline & $(0.70)$ & $(0.80)$ & $(0.60)$ & (1.11) & $(0.60)$ & $(0.86)$ & $(0.88)$ & (1.01) & $(0.72)$ \\
\hline Upper & 0.50 & 0.52 & 0.50 & 0.48 & 0.50 & 0.50 & 0.33 & 0.36 & 0.50 \\
\hline Above upper grade & - & - & - & - & - & - & 0.34 & 0.29 & - \\
\hline \multicolumn{10}{|l|}{ Community location } \\
\hline Geographically isolated & 0.06 & 0.00 & 0.12 & 0.01 & 0.05 & 0.01 & 0.04 & 0.04 & 0.03 \\
\hline Close to town center & 0.35 & 0.22 & 0.12 & 0.62 & 0.44 & 0.23 & 0.46 & 0.23 & 0.44 \\
\hline
\end{tabular}




\section{Table 3: Family Background and Student Performance}

Least-squares regression within each country, weighted by students' sampling probabilities. Dependent variable: TIMSS math test score. Standard errors robust to clustering at the school level in parentheses.

\begin{tabular}{|c|c|c|c|c|c|c|c|c|c|}
\hline & AUS & BFL & BFR & DEN & ENG & FRA & GER & GRE & ICE \\
\hline \multicolumn{10}{|l|}{$\begin{array}{l}\text { Parents' education } \\
\text { Pan }\end{array}$} \\
\hline Some secondary & - & $\begin{array}{r}6.98 \\
(12.03)\end{array}$ & $\begin{array}{l}-19.79^{+} \\
(9.40)\end{array}$ & - & - & $\begin{array}{r}8.38 \\
(6.64)\end{array}$ & - & $\begin{array}{c}9.24^{*} \\
(3.48)\end{array}$ & $\begin{array}{l}25.83^{*} \\
(7.82)\end{array}$ \\
\hline Finished secondary & $\begin{array}{l}16.64^{+} \\
(6.45)\end{array}$ & $\begin{array}{c}20.37^{\circ} \\
(11.08)\end{array}$ & $\begin{array}{l}-11.04 \\
(9.32)\end{array}$ & $\begin{array}{l}14.71^{\circ} \\
(7.53)\end{array}$ & - & $\begin{array}{l}19.63^{*} \\
(6.88)\end{array}$ & $\begin{array}{l}12.42^{*} \\
(3.44)\end{array}$ & $\begin{array}{l}23.00^{*} \\
(3.44)\end{array}$ & $\begin{array}{l}30.75^{*} \\
(8.14)\end{array}$ \\
\hline Some after secondary & - & $\begin{array}{c}37.87^{*} \\
(13.27)\end{array}$ & $\begin{array}{r}2.02 \\
(10.15)\end{array}$ & $\begin{array}{l}24.97^{*} \\
(7.60)\end{array}$ & - & $\begin{array}{l}21.24^{*} \\
(7.16)\end{array}$ & $\begin{array}{l}11.37^{\circ} \\
(6.26)\end{array}$ & $\begin{array}{l}23.01^{*} \\
(5.19)\end{array}$ & $\begin{array}{l}34.81^{*} \\
(6.89)\end{array}$ \\
\hline Finished university & $\begin{array}{l}31.62^{*} \\
(8.27)\end{array}$ & $\begin{array}{c}41.39^{*} \\
(12.18)\end{array}$ & $\begin{array}{r}9.13 \\
(9.71)\end{array}$ & $\begin{array}{l}32.54^{*} \\
(7.39)\end{array}$ & - & $\begin{array}{l}38.25^{*} \\
(6.94)\end{array}$ & $\begin{array}{l}29.51^{*} \\
(5.25)\end{array}$ & $\begin{array}{l}51.28^{*} \\
(4.44)\end{array}$ & $\begin{array}{l}43.36^{*} \\
(7.19)\end{array}$ \\
\hline \multicolumn{10}{|l|}{ Books at home } \\
\hline One shelf (11-25) & $\begin{array}{l}18.22^{*} \\
(4.26)\end{array}$ & $\begin{array}{l}15.86^{*} \\
(5.51)\end{array}$ & $\begin{array}{r}9.66 \\
(6.96)\end{array}$ & $\begin{array}{l}14.74^{\circ} \\
(8.02)\end{array}$ & $\begin{array}{l}24.41^{*} \\
(5.96)\end{array}$ & $\begin{array}{l}-4.62 \\
(4.98)\end{array}$ & $\begin{array}{l}20.06^{*} \\
(4.28)\end{array}$ & $\begin{array}{l}11.15^{*} \\
(3.85)\end{array}$ & $\begin{array}{r}19.23 \\
(11.90)\end{array}$ \\
\hline One bookcase (26-100) & $\begin{array}{l}37.70^{*} \\
(4.67)\end{array}$ & $\begin{array}{l}26.56^{*} \\
(6.20)\end{array}$ & $\begin{array}{l}29.53^{*} \\
(5.00)\end{array}$ & $\begin{array}{l}33.08^{*} \\
(7.73)\end{array}$ & $\begin{array}{l}60.29^{*} \\
(6.45)\end{array}$ & $\begin{array}{r}8.75^{\circ} \\
(4.67)\end{array}$ & $\begin{array}{l}42.78^{*} \\
(4.79)\end{array}$ & $\begin{array}{l}34.16^{*} \\
(4.58)\end{array}$ & $\begin{array}{r}30.46^{*} \\
(10.43)\end{array}$ \\
\hline Two bookcases (101-200) & $\begin{array}{l}62.83^{*} \\
(5.91)\end{array}$ & $\begin{array}{l}33.74^{*} \\
(6.19)\end{array}$ & $\begin{array}{l}36.69^{*} \\
(5.25)\end{array}$ & $\begin{array}{l}45.48^{*} \\
(8.12)\end{array}$ & $\begin{array}{l}81.22^{*} \\
(6.62)\end{array}$ & $\begin{array}{l}16.63^{*} \\
(4.93)\end{array}$ & $\begin{array}{l}65.12^{*} \\
(5.86)\end{array}$ & $\begin{array}{l}44.70^{*} \\
(5.76)\end{array}$ & $\begin{array}{c}44.44^{*} \\
(10.47)\end{array}$ \\
\hline $\begin{array}{l}\text { More than two bookcases } \\
(>200)\end{array}$ & $\begin{array}{l}71.83^{*} \\
(5.25)\end{array}$ & $\begin{array}{l}29.97^{*} \\
(6.45)\end{array}$ & $\begin{array}{l}44.68^{*} \\
(5.45)\end{array}$ & $\begin{array}{l}53.45^{*} \\
(7.63)\end{array}$ & $\begin{array}{c}104.43^{*} \\
(7.77)\end{array}$ & $\begin{array}{l}11.17^{+} \\
(5.23)\end{array}$ & $\begin{array}{l}75.24^{*} \\
(5.34)\end{array}$ & $\begin{array}{l}44.66^{*} \\
(5.64)\end{array}$ & $\begin{array}{r}54.54^{*} \\
(11.39)\end{array}$ \\
\hline Living with both parents & $\begin{array}{l}-2.84 \\
(2.99)\end{array}$ & $\begin{array}{r}-2.28 \\
(4.56)\end{array}$ & $\begin{array}{l}-6.97 \\
(4.36)\end{array}$ & $\begin{array}{r}2.46 \\
(3.82)\end{array}$ & $\begin{array}{r}4.51 \\
(4.27)\end{array}$ & $\begin{array}{r}7.82^{*} \\
(2.46)\end{array}$ & $\begin{array}{c}9.37^{*} \\
(3.10)\end{array}$ & $\begin{array}{l}13.85^{*} \\
(2.46)\end{array}$ & $\begin{array}{r}5.37 \\
(3.98)\end{array}$ \\
\hline Born in country & $\begin{array}{l}25.93^{*} \\
(6.79)\end{array}$ & $\begin{array}{r}8.54 \\
(8.28)\end{array}$ & $\begin{array}{l}18.96^{*} \\
(5.61)\end{array}$ & $\begin{array}{l}20.40^{*} \\
(6.29)\end{array}$ & $\begin{array}{l}10.59 \\
(7.42)\end{array}$ & - & $\begin{array}{l}16.07^{*} \\
(4.89)\end{array}$ & $\begin{array}{r}9.47^{+} \\
(4.47)\end{array}$ & $\begin{array}{l}10.32^{+} \\
(5.22)\end{array}$ \\
\hline Female & $\begin{array}{l}-10.22^{*} \\
(2.95)\end{array}$ & $\begin{array}{r}0.34 \\
(6.42)\end{array}$ & $\begin{array}{l}-13.05^{*} \\
(3.42)\end{array}$ & $\begin{array}{l}-12.56^{*} \\
(2.60)\end{array}$ & $\begin{array}{l}-9.13^{\circ} \\
(4.87)\end{array}$ & $\begin{array}{c}-10.69^{*} \\
(2.04)\end{array}$ & $\begin{array}{l}-8.51^{*} \\
(3.28)\end{array}$ & $\begin{array}{l}-9.73^{*} \\
(1.92)\end{array}$ & $\begin{array}{l}-3.21 \\
(2.83)\end{array}$ \\
\hline Age & $\begin{array}{l}-22.79^{*} \\
(2.68)\end{array}$ & $\begin{array}{l}-36.08^{*} \\
(3.05)\end{array}$ & $\begin{array}{l}-31.36^{*} \\
(1.97)\end{array}$ & $\begin{array}{l}-19.39^{*} \\
(3.37)\end{array}$ & $\begin{array}{r}7.03 \\
(4.99)\end{array}$ & $\begin{array}{l}-24.74^{*} \\
(2.36)\end{array}$ & $\begin{array}{l}-18.67^{*} \\
(2.50)\end{array}$ & $\begin{array}{c}-13.42^{*} \\
(3.34)\end{array}$ & $\begin{array}{r}-0.70 \\
(4.48)\end{array}$ \\
\hline Upper grade & $\begin{array}{l}52.27^{*} \\
(3.73)\end{array}$ & $\begin{array}{l}52.46^{*} \\
(5.14)\end{array}$ & $\begin{array}{l}55.82^{*} \\
(3.92)\end{array}$ & $\begin{array}{l}57.79^{*} \\
(4.68)\end{array}$ & $\begin{array}{l}23.00^{*} \\
(5.30)\end{array}$ & $\begin{array}{l}67.39^{*} \\
(4.36)\end{array}$ & $\begin{array}{l}42.31^{*} \\
(3.78)\end{array}$ & $\begin{array}{l}55.59^{*} \\
(4.62)\end{array}$ & $\begin{array}{l}26.80^{*} \\
(7.57)\end{array}$ \\
\hline Above upper grade & - & - & - & - & - & - & - & - & - \\
\hline & & & & & & & & & \\
\hline Geogi & $\begin{array}{c}50.49^{*} \\
(10.42)\end{array}$ & - & - & $\begin{array}{c}-26.10^{+} \\
(10.19)\end{array}$ & $\begin{array}{c}-11.25 \\
(11.42)\end{array}$ & - & $\begin{array}{r}27.11 \\
(31.11)\end{array}$ & $\begin{array}{r}-7.39 \\
(5.61)\end{array}$ & $\begin{array}{r}-9.71 \\
(5.99)\end{array}$ \\
\hline Close to town center & $\begin{array}{l}15.70^{+} \\
(7.13)\end{array}$ & $\begin{array}{r}-4.48 \\
(8.53)\end{array}$ & $\begin{array}{l}12.82^{+} \\
(6.38)\end{array}$ & $\begin{array}{c}-12.55^{+} \\
(6.11)\end{array}$ & $\begin{array}{r}-12.30 \\
(8.51)\end{array}$ & $\begin{array}{r}2.25 \\
(5.23)\end{array}$ & $\begin{array}{r}4.65 \\
(9.81)\end{array}$ & $\begin{array}{l}15.28^{*} \\
(5.17)\end{array}$ & $\begin{array}{r}2.24 \\
(4.77)\end{array}$ \\
\hline Imputatio & yes & yes & yes & yes & yes & yes & yes & yes & yes \\
\hline$\overline{\text { Studen }}$ & $\overline{c 5786}$ & 5662 & 4883 & 4370 & 3579 & $\overline{6014}$ & $\overline{5763}$ & 7921 & 3730 \\
\hline Sc & 129 & 141 & 120 & 153 & 127 & 134 & 137 & 156 & 155 \\
\hline $\mathrm{R}^{2}$ & 0.187 & 0.149 & 0.243 & 0.142 & 0.157 & 0.230 & 0.218 & 0.201 & 0.118 \\
\hline $\mathrm{R}^{2}$ (without imputation controls) & 0.173 & 0.137 & 0.221 & 0.123 & 0.148 & 0.211 & 0.187 & 0.179 & 0.092 \\
\hline
\end{tabular}

Significance levels (based on standard errors robust to clustering at the school level): ${ }^{*} 1 \% .-{ }^{+} 5 \% .-{ }^{\circ} 10 \%$. 
Table 3 (continued)

\begin{tabular}{|c|c|c|c|c|c|c|c|c|c|}
\hline & IRE & NET & NOR & POR & SCO & SPA & SWE & SWI & USA \\
\hline \multicolumn{10}{|l|}{ Parents' education } \\
\hline Some secondary & $\begin{array}{r}7.65 \\
(5.27)\end{array}$ & $\begin{array}{r}25.63^{+} \\
(10.05)\end{array}$ & - & $\begin{array}{r}5.36^{+} \\
(2.19)\end{array}$ & - & $\begin{array}{r}7.82^{*} \\
(2.57)\end{array}$ & - & - & $\begin{array}{l}11.06 \\
(8.63)\end{array}$ \\
\hline \multirow[t]{2}{*}{ Finished secondary } & $15.60^{*}$ & $24.46^{+}$ & 4.62 & $13.92^{*}$ & -1.58 & $22.19^{*}$ & $13.63^{*}$ & $16.01^{*}$ & $17.20^{\circ}$ \\
\hline & (5.49) & $(10.43)$ & $(9.10)$ & (3.32) & $(4.46)$ & (2.99) & $(4.18)$ & (3.66) & (8.83) \\
\hline \multirow[t]{2}{*}{ Some after secondary } & $25.20^{*}$ & $44.27^{*}$ & $20.28^{+}$ & $24.64^{*}$ & $14.36^{*}$ & $8.90^{*}$ & $22.42^{*}$ & $24.41^{*}$ & $31.48^{*}$ \\
\hline & $(5.60)$ & $(9.44)$ & $(8.20)$ & $(4.15)$ & (5.33) & (3.19) & $(5.00)$ & $(4.71)$ & (8.29) \\
\hline \multirow[t]{2}{*}{ Finished university } & $36.57^{*}$ & $40.71^{*}$ & $27.46^{*}$ & $37.52^{*}$ & $38.07^{*}$ & $19.78^{*}$ & $29.54^{*}$ & $34.98^{*}$ & $52.66^{*}$ \\
\hline & $(6.40)$ & $(10.50)$ & (7.88) & (3.87) & (5.09) & (3.67) & $(4.70)$ & $(4.95)$ & $(9.16)$ \\
\hline \multicolumn{10}{|l|}{ Books at home } \\
\hline \multirow[t]{2}{*}{ One shelf (11-25) } & $13.99^{*}$ & $17.34^{+}$ & 10.20 & $8.81^{*}$ & $26.02^{*}$ & $15.33^{*}$ & 3.66 & $18.97^{*}$ & $9.75^{+}$ \\
\hline & $(4.89)$ & $(7.49)$ & $(9.58)$ & $(2.22)$ & $(3.76)$ & $(4.48)$ & (5.55) & $(4.48)$ & (3.78) \\
\hline \multirow[t]{2}{*}{ One bookcase (26-100) } & $47.36^{*}$ & $37.53^{*}$ & $23.33^{*}$ & $17.93^{*}$ & $48.05^{*}$ & $31.12^{*}$ & $36.84^{*}$ & $39.69^{*}$ & $34.57^{*}$ \\
\hline & (5.06) & (6.77) & (8.81) & (2.55) & (3.87) & $(4.28)$ & (4.99) & (4.66) & (3.56) \\
\hline \multirow[t]{2}{*}{ Two bookcases (101-200) } & $63.70^{*}$ & $51.37^{*}$ & $37.23^{*}$ & $27.44^{*}$ & $69.99^{*}$ & $42.60^{*}$ & $55.93^{*}$ & $57.89^{*}$ & $53.48^{*}$ \\
\hline & (5.30) & (7.04) & (9.34) & (2.99) & (4.79) & $(4.75)$ & (5.01) & (5.30) & (4.23) \\
\hline \multirow{2}{*}{$\begin{array}{l}\text { More than two bookcases } \\
(>200)\end{array}$} & $65.35^{*}$ & $60.37^{*}$ & $54.96^{*}$ & $24.77^{*}$ & $78.56^{*}$ & $49.81^{*}$ & $67.75^{*}$ & $65.88^{*}$ & $62.61^{*}$ \\
\hline & $(5.48)$ & (7.61) & (8.85) & (3.31) & (4.62) & (4.51) & (5.06) & (5.26) & (4.75) \\
\hline \multirow[t]{2}{*}{ Living with both parents } & $14.04^{*}$ & -1.86 & $18.66^{*}$ & 1.79 & $7.18^{+}$ & 0.50 & $5.19^{\circ}$ & $8.34^{*}$ & $15.48^{*}$ \\
\hline & (3.59) & (4.90) & (5.33) & (2.23) & (2.89) & (2.57) & (3.14) & (2.45) & (2.89) \\
\hline \multirow[t]{2}{*}{ Born in country } & $-13.16^{+}$ & 8.71 & $22.34^{*}$ & $-6.07^{+}$ & 2.05 & $14.37^{*}$ & $30.30^{*}$ & $24.27^{*}$ & 1.56 \\
\hline & $(5.76)$ & (6.18) & (4.85) & (3.06) & $(4.31)$ & $(5.06)$ & (4.01) & $(4.06)$ & (4.57) \\
\hline \multirow[t]{2}{*}{ Female } & $-19.67^{*}$ & $-10.68^{*}$ & $-5.59^{+}$ & $-9.79^{*}$ & $-10.56^{*}$ & $-9.70^{*}$ & -2.26 & $-13.26^{*}$ & $-9.01^{*}$ \\
\hline & (4.93) & (3.01) & $(2.27)$ & (1.48) & (2.23) & (2.05) & (2.02) & $(2.01)$ & (2.33) \\
\hline \multirow[t]{2}{*}{ Age } & $-26.67^{*}$ & $-29.41^{*}$ & 2.42 & $-12.85^{*}$ & $8.79^{+}$ & $-20.97^{*}$ & -1.63 & $-17.11^{*}$ & $-22.09^{*}$ \\
\hline & $(2.45)$ & (2.99) & (3.81) & $(0.90)$ & (4.14) & (1.44) & (3.13) & (3.47) & (2.61) \\
\hline \multirow[t]{2}{*}{ Upper grade } & $54.68^{*}$ & $60.93^{*}$ & $40.33^{*}$ & $43.20^{*}$ & $27.18^{*}$ & $59.25^{*}$ & $39.56^{*}$ & $60.23^{*}$ & $45.99^{*}$ \\
\hline & (5.32) & $(6.80)$ & $(4.54)$ & $(2.22)$ & (5.84) & $(2.45)$ & $(4.55)$ & $(5.51)$ & $(4.44)$ \\
\hline Above upper grade & - & - & - & - & - & - & $\begin{array}{l}74.06^{*} \\
(7.54)\end{array}$ & $\begin{array}{r}118.93^{*} \\
(9.23)\end{array}$ & - \\
\hline \multicolumn{10}{|l|}{ Community location } \\
\hline \multirow[t]{2}{*}{ Geographically isolated } & 6.71 & - & 6.98 & $-20.87^{*}$ & $12.15^{\circ}$ & $-46.10^{*}$ & -19.35 & 4.85 & $-28.90 *$ \\
\hline & (12.83) & & $(7.42)$ & (4.99) & $(6.71)$ & $(2.22)$ & $(13.76)$ & $(14.67)$ & (7.95) \\
\hline \multirow[t]{2}{*}{ Close to town center } & 5.62 & 15.01 & 7.11 & 0.38 & -3.31 & 2.37 & $10.04^{*}$ & -5.74 & -4.11 \\
\hline & $(6.47)$ & (10.67) & (5.74) & $(3.00)$ & (5.08) & $(4.52)$ & (3.88) & (8.85) & (6.64) \\
\hline Imputation controls & yes & yes & yes & yes & yes & yes & yes & yes & yes \\
\hline Students [unit of observation] & 6203 & 4084 & 5736 & 6753 & 5776 & 7596 & 8855 & 11722 & 10973 \\
\hline Schools [unit of clustering] & 132 & 95 & 249 & 142 & 128 & 154 & 270 & 327 & 183 \\
\hline $\mathrm{R}^{2}$ & 0.180 & 0.207 & 0.147 & 0.200 & 0.214 & 0.205 & 0.232 & 0.272 & 0.185 \\
\hline $\mathrm{R}^{2}$ (without imputation controls) & 0.162 & 0.187 & 0.135 & 0.196 & 0.200 & 0.199 & 0.219 & 0.264 & 0.175 \\
\hline
\end{tabular}

Significance levels (based on standard errors robust to clustering at the school level): ${ }^{*} 1 \%$. - ${ }^{+} 5 \%$. - ${ }^{\circ} 10 \%$. 
Table 4: Family-Background Effects in Europe vs. the United States

Least-squares regression pooling all countries, weighted by students' sampling probabilities.

Dependent variable: TIMSS math test score. Standard errors robust to clustering at the school level in parentheses.

\begin{tabular}{lcc}
\hline \hline & All countries & Interaction with \\
Europe dummy
\end{tabular}

Significance levels (based on standard errors robust to clustering at the school level): ${ }^{*} 1 \% .-{ }^{+} 5 \% .-{ }^{\circ} 10 \%$. 


\section{Figure 1: Quantile Regression Estimates of Family-Background Effects}

Coefficients on the four books-at-home categories in the model of Table 3. - Horizontal lines: WLS estimates. - Curved lines with dots: Quantile regression estimates for 0.05 intervals. - Categories (residual $=$ less than one shelf): $\bullet$ One shelf. $-\rightarrow$ One bookcase. $-\bullet$ - Two bookcases. $\rightarrow \rightarrow$ More than two bookcases.
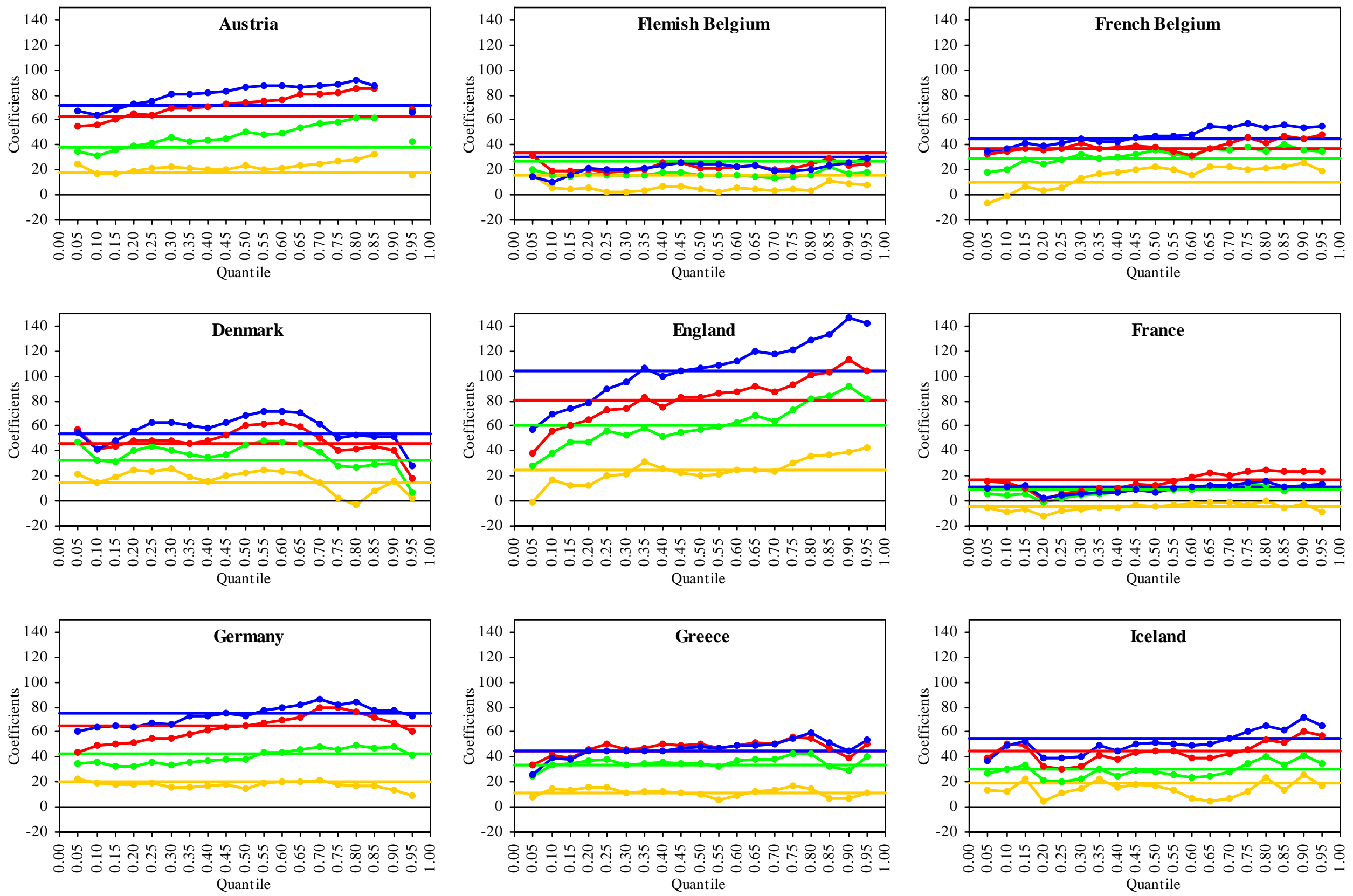
Figure 1 (cont.)
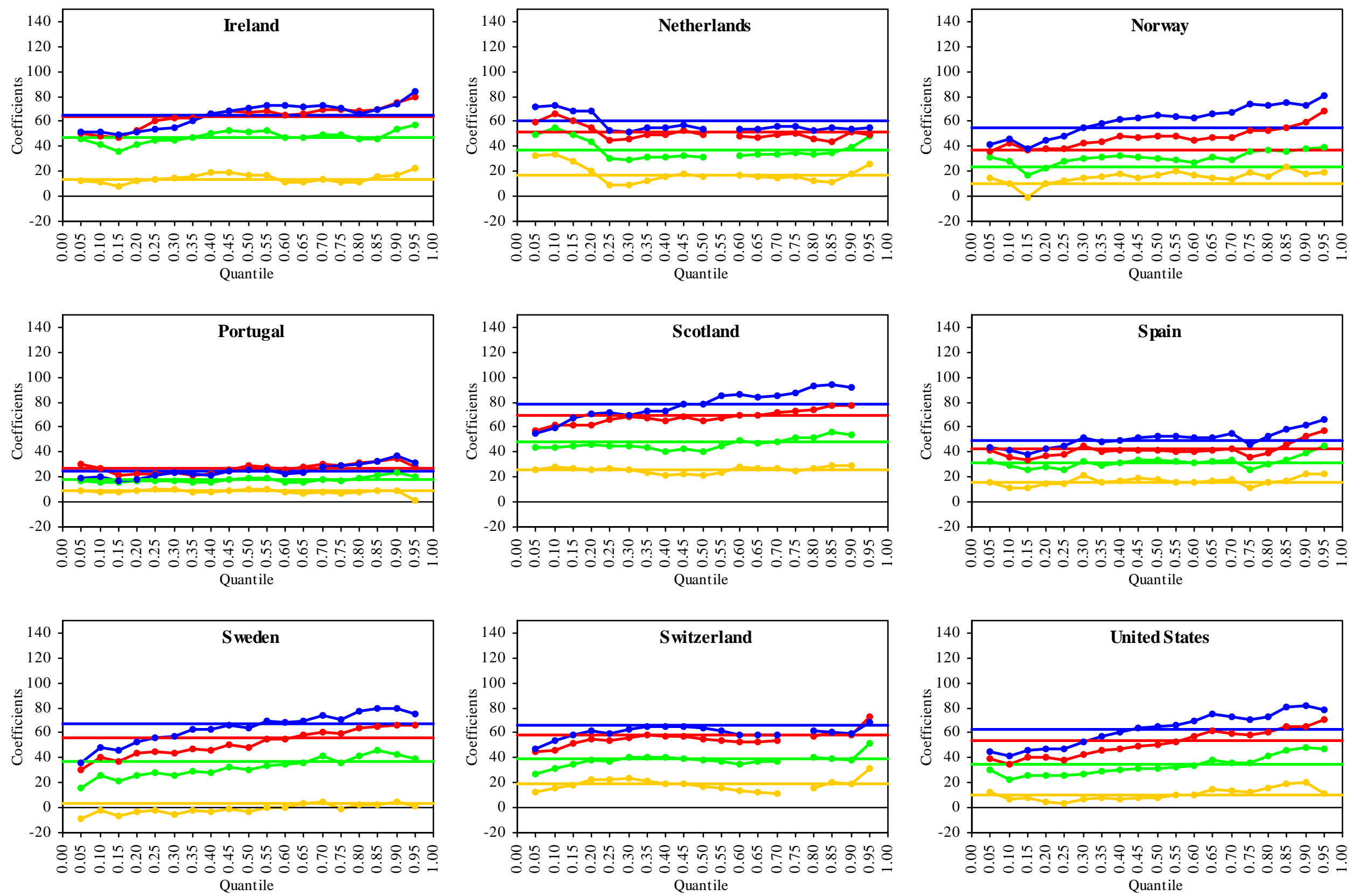


\section{Figure 2: Family-Background Effects and Mean Performance}

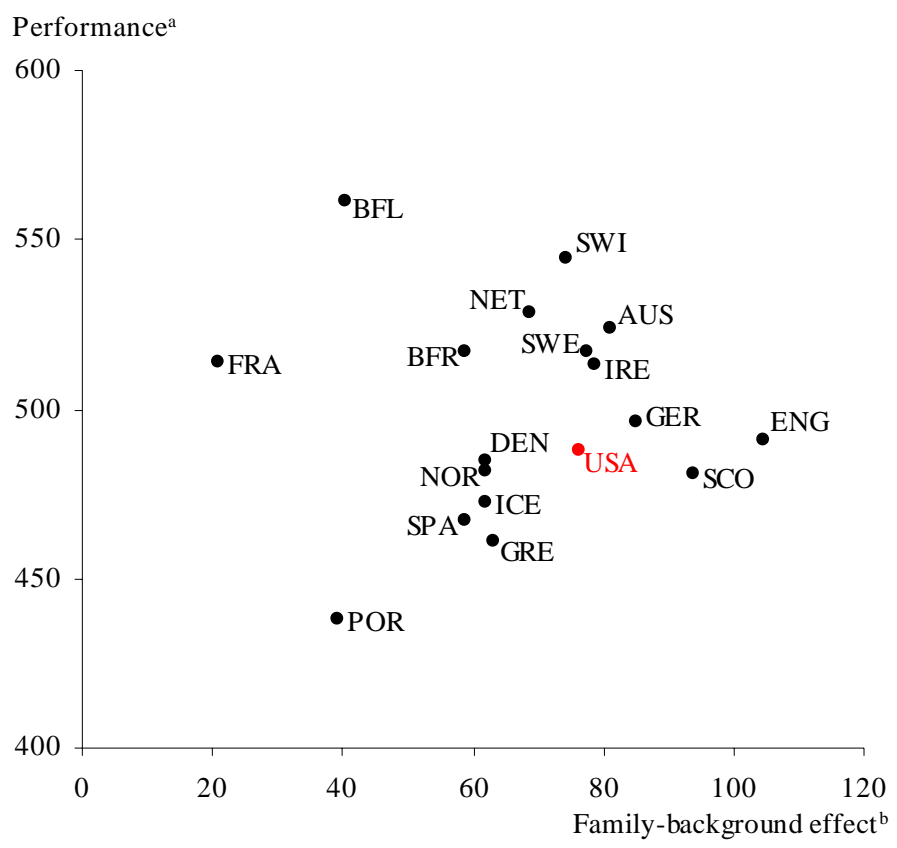

Notes: ${ }^{a}$ Mean performance on the TIMSS math test (cf. Table 1). $-{ }^{\mathrm{b}}$ Performance difference between students with more than two bookcases at home and students with less than one shelf of books at home, controlling for the variables reported in Table 3 except for parental education. 


\section{Appendix 1: Imputation of Missing Data within Each Country}

Some students and school principals failed to answer some questionnaire items in the background questionnaires. Table A1 reports the share of missing values for each variable in each country. For the analyses in this paper, data for missing responses in the TIMSS questionnaires were imputed within each country based on a method that relates the observations from students with original data to a set of "fundamental" explanatory variables available for all students.

Specifically, the following set of "fundamental” variables $F$ has data available for virtually all students in most countries: grade level; student sex; student age; four dummies for the parents' education level; four dummies for the number of books in the student's home; and three dummies for the community location of the schools. Missing data on variables within $F$ were imputed by the median category observed at the lowest level available, i.e., either the class median, the school median, or the country median.

The variables in $F$ were then used to impute missing data on the remaining variables $M$ for each student $i$ within each country. Let $S$ denote the set of students $j$ with available data for $M$. Using the students in $S$, the variable $M$ was regressed on $F$ :

$$
M_{j \in S}=F_{j \in S} \phi+\varepsilon_{j \in S}
$$

Since the $M$ variables considered in this paper are dichotomous (binary) variables, the regression model was a probit model was used, weighting each student by her sampling probability. Finally, the coefficients $\phi$ from these regressions and the data on $F_{i}$ were used to impute the value of $M_{i}$ for the students with missing data:

$$
\tilde{M}_{i \notin S}=F_{i \notin S} \phi
$$

The coefficients estimated by the probit models were used to forecast the probability of occurrence associated with each category for the students with missing data, and the category with the highest probability was imputed. This data imputation technique was applied within each country individually, resulting in a complete data set for all the students sampled in TIMSS. 


\section{Appendix 2: Appendix Tables}

Table A1: Missing Values

Fraction of students with missing data, not weighted.

\begin{tabular}{|c|c|c|c|c|c|c|c|c|c|}
\hline & AUS & $\mathrm{BFL}$ & BFR & DEN & ENG & FRA & GER & GRE & ICE \\
\hline Parents' education & 0.22 & 0.33 & 0.35 & 0.42 & 1.00 & 0.45 & 0.29 & 0.17 & 0.23 \\
\hline Books at home & 0.04 & 0.01 & 0.02 & 0.06 & 0.02 & 0.04 & 0.02 & 0.02 & 0.02 \\
\hline Living with both parents & 0.07 & 0.02 & 0.02 & 0.06 & 0.02 & 0.05 & 0.03 & 0.04 & 0.05 \\
\hline Born in country & 0.03 & 0.00 & 0.02 & 0.05 & 0.02 & 1.00 & 0.01 & 0.01 & 0.01 \\
\hline Sex & 0.03 & 0.00 & 0.02 & 0.02 & 0.00 & 0.04 & 0.01 & 0.00 & 0.00 \\
\hline Age & 0.03 & 0.00 & 0.03 & 0.02 & 0.00 & 0.07 & 0.03 & 0.00 & 0.00 \\
\hline Community location & 0.13 & 0.10 & 0.17 & 0.19 & 0.15 & 0.11 & 0.40 & 0.03 & 0.10 \\
\hline
\end{tabular}

Table A1 (cont.)

\begin{tabular}{|c|c|c|c|c|c|c|c|c|c|}
\hline & IRE & NET & NOR & POR & SCO & SPA & SWE & SWI & USA \\
\hline Parents' education & 0.15 & 0.29 & 0.35 & 0.10 & 0.49 & 0.16 & 0.38 & 0.22 & 0.10 \\
\hline Books at home & 0.02 & 0.04 & 0.02 & 0.01 & 0.07 & 0.01 & 0.02 & 0.02 & 0.02 \\
\hline Living with both parents & 0.03 & 0.04 & 0.01 & 0.02 & 0.08 & 0.03 & 0.03 & 0.02 & 0.03 \\
\hline Born in country & 0.01 & 0.04 & 0.01 & 0.01 & 0.06 & 0.01 & 0.01 & 0.01 & 0.02 \\
\hline Sex & 0.00 & 0.01 & 0.00 & 0.00 & 0.00 & 0.00 & 0.00 & 0.00 & 0.00 \\
\hline Age & 0.00 & 0.01 & 0.00 & 0.00 & 0.00 & 0.00 & 0.00 & 0.00 & 0.00 \\
\hline Community location & 0.04 & 0.19 & 0.14 & 0.06 & 0.18 & 0.06 & 0.08 & 0.13 & 0.15 \\
\hline
\end{tabular}


Table A2: Family Background and Science Performance

Least-squares regression within each country, weighted by students’ sampling probabilities.

Dependent variable: TIMSS science test score. Standard errors robust to clustering at the school level in parentheses.

\begin{tabular}{|c|c|c|c|c|c|c|c|c|c|}
\hline & AUS & BFL & BFR & DEN & ENG & FRA & GER & GRE & ICE \\
\hline \multicolumn{10}{|l|}{ Parents' education } \\
\hline Some secondary & - & $\begin{array}{r}-3.11 \\
(7.17)\end{array}$ & $\begin{array}{r}2.99 \\
(11.01)\end{array}$ & - & - & $\begin{array}{r}5.60 \\
(5.91)\end{array}$ & - & $\begin{array}{c}8.71^{+} \\
(3.55)\end{array}$ & $\begin{array}{l}17.65^{+} \\
(8.27)\end{array}$ \\
\hline Finished secondary & $\begin{array}{l}18.70^{*} \\
(5.95)\end{array}$ & $\begin{array}{r}7.10 \\
(6.12)\end{array}$ & $\begin{array}{r}15.35 \\
(9.91)\end{array}$ & $\begin{array}{l}10.23 \\
(7.93)\end{array}$ & - & $\begin{array}{l}12.39^{\circ} \\
(6.38)\end{array}$ & $\begin{array}{r}7.59^{\circ} \\
(3.90)\end{array}$ & $\begin{array}{l}19.85^{*} \\
(3.42)\end{array}$ & $\begin{array}{l}16.24^{\circ} \\
(8.53)\end{array}$ \\
\hline Some after secondary & - & $\begin{array}{l}28.68^{*} \\
(8.68)\end{array}$ & $\begin{array}{r}21.34^{+} \\
(10.73)\end{array}$ & $\begin{array}{l}29.79^{*} \\
(8.01)\end{array}$ & - & $\begin{array}{l}21.30^{*} \\
(6.86)\end{array}$ & $\begin{array}{l}18.88^{*} \\
(5.54)\end{array}$ & $\begin{array}{l}19.48^{*} \\
(4.32)\end{array}$ & $\begin{array}{l}29.29^{*} \\
(7.41)\end{array}$ \\
\hline Finished university & $\begin{array}{l}30.50^{*} \\
(7.45)\end{array}$ & $\begin{array}{l}24.05^{*} \\
(6.46)\end{array}$ & $\begin{array}{r}29.42^{*} \\
(10.83)\end{array}$ & $\begin{array}{c}29.17^{*} \\
(7.88)\end{array}$ & - & $\begin{array}{l}26.84^{*} \\
(6.25)\end{array}$ & $\begin{array}{l}22.81^{*} \\
(5.53)\end{array}$ & $\begin{array}{l}37.39^{*} \\
(4.37)\end{array}$ & $\begin{array}{l}33.61^{*} \\
(8.15)\end{array}$ \\
\hline \multicolumn{10}{|l|}{ Books at home } \\
\hline One shelf (11-25) & $\begin{array}{l}17.80^{*} \\
(5.34)\end{array}$ & $\begin{array}{l}14.85^{+} \\
(5.92)\end{array}$ & $\begin{array}{c}19.37^{*} \\
(5.86)\end{array}$ & $\begin{array}{c}20.54^{+} \\
(8.89)\end{array}$ & $\begin{array}{l}30.03^{*} \\
(6.30)\end{array}$ & $\begin{array}{r}8.95 \\
(5.47)\end{array}$ & $\begin{array}{c}32.28^{*} \\
(5.71)\end{array}$ & $\begin{array}{l}13.99^{*} \\
(4.40)\end{array}$ & $\begin{array}{r}-5.48 \\
(15.91)\end{array}$ \\
\hline One bookcase (26-100) & $\begin{array}{l}38.07^{*} \\
(5.48)\end{array}$ & $\begin{array}{l}24.08^{*} \\
(5.62)\end{array}$ & $\begin{array}{l}37.04^{*} \\
(5.81)\end{array}$ & $\begin{array}{l}34.82^{*} \\
(7.44)\end{array}$ & $\begin{array}{c}63.98^{*} \\
(6.45)\end{array}$ & $\begin{array}{l}24.64^{*} \\
(4.88)\end{array}$ & $\begin{array}{l}56.43^{*} \\
(5.30)\end{array}$ & $\begin{array}{l}34.94^{*} \\
(4.69)\end{array}$ & $\begin{array}{r}12.82 \\
(14.14)\end{array}$ \\
\hline Two bookcases (101-200) & $\begin{array}{l}59.14^{*} \\
(5.58)\end{array}$ & $\begin{array}{l}35.01^{*} \\
(5.07)\end{array}$ & $\begin{array}{l}50.94^{*} \\
(5.54)\end{array}$ & $\begin{array}{l}51.75^{*} \\
(7.91)\end{array}$ & $\begin{array}{l}91.62^{*} \\
(6.91)\end{array}$ & $\begin{array}{l}33.23^{*} \\
(5.36)\end{array}$ & $\begin{array}{l}78.56^{*} \\
(6.70)\end{array}$ & $\begin{array}{l}42.92^{*} \\
(5.39)\end{array}$ & $\begin{array}{r}22.93 \\
(15.28)\end{array}$ \\
\hline $\begin{array}{l}\text { More than two bookcases } \\
\quad(>200)\end{array}$ & $\begin{array}{l}69.18^{*} \\
(5.95)\end{array}$ & $\begin{array}{l}34.66^{*} \\
(5.57)\end{array}$ & $\begin{array}{l}55.32^{*} \\
(5.12)\end{array}$ & $\begin{array}{l}61.86^{*} \\
(7.44)\end{array}$ & $\begin{array}{l}121.06^{*} \\
(7.60)\end{array}$ & $\begin{array}{l}29.40^{*} \\
(5.27)\end{array}$ & $\begin{array}{l}90.76^{*} \\
(5.61)\end{array}$ & $\begin{array}{l}44.35^{*} \\
(5.23)\end{array}$ & $\begin{array}{r}37.13^{+} \\
(14.39)\end{array}$ \\
\hline Living with both parents & $\begin{array}{r}-3.61 \\
(3.66)\end{array}$ & $\begin{array}{r}-1.47 \\
(3.54)\end{array}$ & $\begin{array}{l}-7.89^{+} \\
(3.19)\end{array}$ & $\begin{array}{r}-2.12 \\
(4.05)\end{array}$ & $\begin{array}{r}0.75 \\
(4.63)\end{array}$ & $\begin{array}{r}4.94^{\circ} \\
(2.97)\end{array}$ & $\begin{array}{r}1.94 \\
(3.73)\end{array}$ & $\begin{array}{c}6.91^{*} \\
(2.60)\end{array}$ & $\begin{array}{r}7.34^{\circ} \\
(3.77)\end{array}$ \\
\hline Born in country & $\begin{array}{l}44.14^{*} \\
(6.88)\end{array}$ & $\begin{array}{r}2.57 \\
(8.02)\end{array}$ & $\begin{array}{r}8.60 \\
(5.78)\end{array}$ & $\begin{array}{l}25.41^{*} \\
(7.95)\end{array}$ & $\begin{array}{l}22.17^{+} \\
(8.73)\end{array}$ & - & $\begin{array}{l}33.02^{*} \\
(5.22)\end{array}$ & $\begin{array}{r}5.88 \\
(4.67)\end{array}$ & $\begin{array}{r}6.91 \\
(5.49)\end{array}$ \\
\hline Female & $\begin{array}{l}-17.05^{*} \\
(3.46)\end{array}$ & $\begin{array}{l}-16.49^{*} \\
(4.45)\end{array}$ & $\begin{array}{l}-19.74^{*} \\
(3.23)\end{array}$ & $\begin{array}{l}-27.73^{*} \\
(2.53)\end{array}$ & $\begin{array}{c}-19.89^{*} \\
(5.04)\end{array}$ & $\begin{array}{l}-19.69^{*} \\
(2.37)\end{array}$ & $\begin{array}{l}-20.34^{*} \\
(3.49)\end{array}$ & $\begin{array}{c}-15.02^{*} \\
(2.35)\end{array}$ & $\begin{array}{l}-15.10^{*} \\
(2.84)\end{array}$ \\
\hline Age & $\begin{array}{c}-18.97^{*} \\
(2.92)\end{array}$ & $\begin{array}{c}-18.63^{*} \\
(2.93)\end{array}$ & $\begin{array}{c}-17.13^{*} \\
(1.90)\end{array}$ & $\begin{array}{c}-15.04^{*} \\
(3.24)\end{array}$ & $\begin{array}{l}19.33^{*} \\
(5.25)\end{array}$ & $\begin{array}{c}-16.41^{*} \\
(1.77)\end{array}$ & $\begin{array}{r}-15.86^{*} \\
(2.73)\end{array}$ & $\begin{array}{c}-10.02^{*} \\
(3.64)\end{array}$ & $\begin{array}{r}7.43^{\circ} \\
(4.48)\end{array}$ \\
\hline Upper grade & $\begin{array}{l}57.24^{*} \\
(4.51)\end{array}$ & $\begin{array}{l}46.26^{*} \\
(3.91)\end{array}$ & $\begin{array}{l}48.94^{*} \\
(3.52)\end{array}$ & $\begin{array}{l}55.15^{*} \\
(4.40)\end{array}$ & $\begin{array}{l}21.66^{*} \\
(5.45)\end{array}$ & $\begin{array}{c}60.68^{*} \\
(2.89)\end{array}$ & $\begin{array}{l}46.93^{*} \\
(4.29)\end{array}$ & $\begin{array}{l}56.24^{*} \\
(4.61)\end{array}$ & $\begin{array}{l}23.19^{*} \\
(7.29)\end{array}$ \\
\hline Above upper grade & - & - & - & - & - & - & - & - & - \\
\hline Community location & & & & & & & & & \\
\hline Geographically isolated & $\begin{array}{l}47.91^{*} \\
(5.40)\end{array}$ & - & - & $\begin{array}{r}-12.44 \\
(9.47)\end{array}$ & $\begin{array}{l}-9.77 \\
(8.54)\end{array}$ & - & $\begin{array}{r}10.52 \\
(26.34)\end{array}$ & $\begin{array}{r}-13.38^{\circ} \\
(7.86)\end{array}$ & $\begin{array}{c}-15.48^{+} \\
(6.77)\end{array}$ \\
\hline Close to town center & $\begin{array}{l}14.76^{+} \\
(6.58)\end{array}$ & $\begin{array}{l}-6.42 \\
(5.26)\end{array}$ & $\begin{array}{r}7.45 \\
(5.07)\end{array}$ & $\begin{array}{c}-10.60^{+} \\
(5.21)\end{array}$ & $\begin{array}{r}-12.15 \\
(7.70)\end{array}$ & $\begin{array}{r}2.81 \\
(3.70)\end{array}$ & $\begin{array}{r}6.84 \\
(8.73)\end{array}$ & $\begin{array}{c}11.98^{*} \\
(4.27)\end{array}$ & $\begin{array}{r}-2.69 \\
(5.10)\end{array}$ \\
\hline Imputation controls & yes & yes & yes & yes & yes & yes & yes & yes & yes \\
\hline Students [unit of observation] & 5786 & 5662 & 4883 & 4370 & 3579 & 6014 & 5763 & 7921 & 3730 \\
\hline Schools [unit of clustering] & 129 & 141 & 120 & 153 & 127 & 134 & 137 & 156 & 155 \\
\hline $\mathrm{R}^{2}$ & 0.175 & 0.113 & 0.183 & 0.155 & 0.178 & 0.183 & 0.210 & 0.180 & 0.114 \\
\hline $\mathrm{R}^{2}$ (without imputation controls) & 0.162 & 0.108 & 0.170 & 0.133 & 0.172 & 0.171 & 0.181 & 0.156 & 0.092 \\
\hline
\end{tabular}

Significance levels (based on standard errors robust to clustering at the school level): ${ }^{*} 1 \% .-{ }^{+} 5 \% .-{ }^{\circ} 10 \%$. 
Table A2 (continued)

\begin{tabular}{|c|c|c|c|c|c|c|c|c|c|}
\hline & IRE & NET & NOR & POR & SCO & SPA & SWE & SWI & USA \\
\hline \multicolumn{10}{|l|}{ Parents' education } \\
\hline Some secondary & $\begin{array}{r}7.84 \\
(5.70)\end{array}$ & $\begin{array}{l}26.82^{*} \\
(8.70)\end{array}$ & - & $\begin{aligned} & 7.17^{*} \\
&(2.44)\end{aligned}$ & - & $\begin{array}{l}10.60^{*} \\
(2.87)\end{array}$ & - & - & $\begin{array}{r}-9.81 \\
(10.16)\end{array}$ \\
\hline \multirow[t]{2}{*}{ Finished secondary } & $11.82^{+}$ & $31.63^{*}$ & 5.80 & $12.94^{*}$ & -4.73 & $19.57^{*}$ & $13.69^{*}$ & $21.65^{*}$ & 5.22 \\
\hline & $(5.51)$ & $(9.51)$ & $(6.45)$ & $(4.27)$ & $(5.36)$ & $(3.74)$ & (4.99) & $(3.12)$ & $(10.18)$ \\
\hline \multirow[t]{2}{*}{ Some after secondary } & $22.41^{*}$ & $49.55^{*}$ & $21.69^{*}$ & $23.73^{*}$ & $12.30^{+}$ & $9.63^{*}$ & $13.93^{+}$ & $22.85^{*}$ & $18.55^{\circ}$ \\
\hline & $(5.22)$ & $(8.43)$ & $(5.39)$ & $(4.87)$ & $(5.37)$ & $(3.53)$ & $(5.55)$ & $(4.52)$ & $(9.68)$ \\
\hline \multirow[t]{2}{*}{ Finished university } & $30.81^{*}$ & $42.27^{*}$ & $26.60^{*}$ & $36.18^{*}$ & $31.25^{*}$ & $19.17^{*}$ & $29.44^{*}$ & $38.55^{*}$ & $34.47^{*}$ \\
\hline & $(5.67)$ & (9.64) & (6.03) & $(4.46)$ & $(5.76)$ & (3.93) & $(5.10)$ & $(4.58)$ & $(10.08)$ \\
\hline \multicolumn{10}{|l|}{ Books at home } \\
\hline \multirow[t]{2}{*}{ One shelf (11-25) } & $24.35^{*}$ & 6.06 & $20.25^{+}$ & $6.53^{\circ}$ & $30.64^{*}$ & $12.23^{+}$ & $17.13^{+}$ & $19.75^{*}$ & $15.78^{*}$ \\
\hline & $(5.12)$ & $(6.05)$ & $(10.03)$ & $(3.31)$ & $(5.05)$ & $(4.91)$ & $(6.79)$ & $(5.27)$ & $(4.82)$ \\
\hline \multirow[t]{2}{*}{ One bookcase (26-100) } & $51.87^{*}$ & $22.67^{*}$ & $34.54^{*}$ & $14.96^{*}$ & $50.76^{*}$ & $28.58^{*}$ & $43.75^{*}$ & $39.45^{*}$ & $48.24^{*}$ \\
\hline & $(5.27)$ & $(5.61)$ & $(9.35)$ & $(3.30)$ & $(4.34)$ & $(4.68)$ & (6.39) & $(4.54)$ & $(4.81)$ \\
\hline \multirow[t]{2}{*}{ Two bookcases (101-200) } & $71.79^{*}$ & $40.33^{*}$ & $51.32^{*}$ & $21.78^{*}$ & $82.09^{*}$ & $38.80^{*}$ & $66.53^{*}$ & $55.97^{*}$ & $67.22^{*}$ \\
\hline & $(5.14)$ & $(6.57)$ & $(9.03)$ & $(3.49)$ & $(5.27)$ & $(4.98)$ & $(6.72)$ & $(4.84)$ & $(5.16)$ \\
\hline \multirow{2}{*}{$\begin{array}{l}\text { More than two bookcases } \\
(>200)\end{array}$} & $74.97^{*}$ & $46.82^{*}$ & $66.05^{*}$ & $30.70^{*}$ & $93.53^{*}$ & $45.33^{*}$ & $78.55^{*}$ & $69.22^{*}$ & $79.10^{*}$ \\
\hline & $(5.94)$ & $(6.36)$ & $(9.10)$ & (3.99) & $(5.10)$ & $(5.07)$ & $(6.30)$ & $(5.05)$ & $(6.01)$ \\
\hline \multirow[t]{2}{*}{ Living with both parents } & 4.69 & -3.23 & $6.98^{\circ}$ & -1.95 & $6.68^{+}$ & 0.23 & 2.16 & -3.92 & $14.37^{*}$ \\
\hline & $(3.36)$ & $(4.83)$ & $(3.60)$ & $(2.60)$ & $(3.30)$ & (3.21) & $(3.36)$ & $(2.48)$ & $(3.51)$ \\
\hline \multirow[t]{2}{*}{ Born in country } & $-16.06^{*}$ & $23.94^{*}$ & $36.11^{*}$ & -2.90 & $-9.03^{\circ}$ & $12.50^{+}$ & $41.81^{*}$ & $34.64^{*}$ & $17.61^{*}$ \\
\hline & $(5.39)$ & $(6.07)$ & $(5.99) *$ & $(3.89) *$ & $(5.12)$ & $(5.63)$ & $(4.16)_{*}$ & $(3.63) *$ & $(4.97)$ \\
\hline \multirow[t]{2}{*}{ Female } & $-19.10^{*}$ & $-18.68^{*}$ & $-14.77^{*}$ & $-19.92^{*}$ & $-20.40^{*}$ & $-21.64^{*}$ & $-11.02^{*}$ & $-20.47^{*}$ & $-15.14^{*}$ \\
\hline & $(4.02)$ & (2.98) & $(2.56)$ & $(1.79)$ & $(2.49)$ & $(1.96)$ & (1.97) & $(2.10)$ & $(2.68)$ \\
\hline \multirow[t]{2}{*}{ Age } & $-16.55^{*}$ & $-17.98^{*}$ & 4.72 & $-11.68^{*}$ & $12.60^{*}$ & $-15.60^{*}$ & 0.73 & $-10.03^{*}$ & $-17.24^{*}$ \\
\hline & $(2.42)$ & (3.25) & (3.73) & (1.13) & $(4.13)$ & $(1.78)$ & (2.93) & $(3.06)$ & $(2.92)$ \\
\hline \multirow[t]{2}{*}{ Upper grade } & $58.96^{*}$ & $65.69^{*}$ & $39.59^{*}$ & $62.00^{*}$ & $36.45^{*}$ & $54.49^{*}$ & $43.23^{*}$ & $50.53^{*}$ & $43.01^{*}$ \\
\hline & $(5.08)$ & (5.53) & $(4.70)$ & $(2.27)$ & (5.56) & (2.64) & $(4.39)$ & $(4.60)$ & $(4.92)$ \\
\hline \multirow[t]{2}{*}{ Above upper grade } & - & - & - & - & - & - & $74.97^{*}$ & $100.93^{*}$ & - \\
\hline & & & & & & & $(7.00)$ & $(8.00)$ & \\
\hline \multicolumn{10}{|l|}{ Community location } \\
\hline \multirow[t]{2}{*}{ Geographically isolated } & -0.67 & - & $16.44^{*}$ & $-13.90^{*}$ & $15.60^{\circ}$ & $-37.70^{*}$ & -5.03 & -8.93 & $-40.68^{*}$ \\
\hline & $(13.34)$ & & $(5.04)$ & $(3.92)$ & $(9.16)$ & $(1.92)$ & $(8.23)$ & $(10.68)$ & $(9.11)$ \\
\hline \multirow[t]{2}{*}{ Close to town center } & 2.86 & $13.58^{\circ}$ & 1.63 & 3.35 & -8.06 & 2.86 & $8.83^{+}$ & -5.22 & $-13.79^{+}$ \\
\hline & $(5.30)$ & $(8.13)$ & (5.13) & $(3.03)$ & $(5.08)$ & $(4.34)$ & (3.59) & $(6.40)$ & $(6.07)$ \\
\hline Imputation controls & yes & yes & yes & yes & yes & yes & yes & yes & yes \\
\hline Students [unit of observation] & 6203 & 4084 & 5736 & 6753 & 5776 & 7596 & 8855 & 11722 & 10973 \\
\hline Schools [unit of clustering] & 132 & 95 & 249 & 142 & 128 & 154 & 270 & 327 & 183 \\
\hline $\mathrm{R}^{2}$ & 0.178 & 0.203 & 0.140 & 0.216 & 0.231 & 0.165 & 0.236 & 0.255 & 0.174 \\
\hline $\mathrm{R}^{2}$ (without imputation controls) & 0.160 & 0.185 & 0.127 & 0.215 & 0.217 & 0.158 & 0.225 & 0.247 & 0.161 \\
\hline
\end{tabular}

Significance levels (based on standard errors robust to clustering at the school level): ${ }^{*} 1 \% .-{ }^{+} 5 \%$. - ${ }^{\circ} 10 \%$. 
Table A3: Family-Background Effects in Europe vs. the United States in Science

Least-squares regression pooling all countries, weighted by students' sampling probabilities.

Dependent variable: TIMSS science test score. Standard errors robust to clustering at the school level in parentheses.

\begin{tabular}{|c|c|c|}
\hline & All countries & $\begin{array}{l}\text { Interaction with } \\
\text { Europe dummy }\end{array}$ \\
\hline \multicolumn{3}{|l|}{ Parents' education } \\
\hline Some secondary & $\begin{array}{l}-4.79 \\
(9.26)\end{array}$ & $\begin{array}{l}10.29 \\
(9.35)\end{array}$ \\
\hline Finished secondary & $\begin{array}{r}7.16 \\
(8.81)\end{array}$ & $\begin{array}{r}4.49 \\
(8.88)\end{array}$ \\
\hline Some after secondary & $\begin{array}{l}20.01^{+} \\
(8.62)\end{array}$ & $\begin{array}{r}1.41 \\
(8.73)\end{array}$ \\
\hline Finished university & $\begin{array}{l}36.79^{*} \\
(9.17)\end{array}$ & $\begin{array}{r}-9.61 \\
(9.28)\end{array}$ \\
\hline \multicolumn{3}{|l|}{ Books at home } \\
\hline One shelf (11-25) & $\begin{array}{l}15.03^{*} \\
(4.76)\end{array}$ & $\begin{array}{r}5.09 \\
(4.98)\end{array}$ \\
\hline One bookcase (26-100) & $\begin{array}{l}49.17^{*} \\
(4.86)\end{array}$ & $\begin{array}{r}-8.94^{\circ} \\
(5.08)\end{array}$ \\
\hline Two bookcases (101-200) & $\begin{array}{l}67.25^{*} \\
(5.04)\end{array}$ & $\begin{array}{r}-9.83^{\circ} \\
(5.26)\end{array}$ \\
\hline $\begin{array}{l}\text { More than two bookcases } \\
(>200)\end{array}$ & $\begin{array}{l}79.62^{*} \\
(5.79)\end{array}$ & $\begin{array}{l}-11.59^{\circ} \\
(5.99)\end{array}$ \\
\hline Living with both parents & $\begin{array}{l}14.78^{*} \\
(3.55)\end{array}$ & $\begin{array}{l}-13.16^{*} \\
(3.66)\end{array}$ \\
\hline Born in country & $\begin{array}{l}18.57^{*} \\
(5.17)\end{array}$ & $\begin{array}{r}0.96 \\
(5.40)\end{array}$ \\
\hline Female & $\begin{array}{c}-15.13^{*} \\
(2.64)\end{array}$ & $\begin{array}{r}-3.10 \\
(2.76)\end{array}$ \\
\hline Age & $\begin{array}{l}-17.49^{*} \\
(2.94)\end{array}$ & $\begin{array}{r}5.62^{\circ} \\
(3.02)\end{array}$ \\
\hline Upper grade & $\begin{array}{l}43.31^{*} \\
(4.90)\end{array}$ & $\begin{array}{r}8.72^{\circ} \\
(5.02)\end{array}$ \\
\hline Above upper grade & $\begin{array}{c}102.21^{*} \\
(2.96)\end{array}$ & - \\
\hline Community location & & \\
\hline Geographically isolated & $\begin{array}{l}-40.19^{*} \\
(8.96)\end{array}$ & $\begin{array}{l}40.05^{*} \\
(9.62)\end{array}$ \\
\hline Close to town center & $\begin{array}{l}-18.15^{*} \\
(5.98)\end{array}$ & $\begin{array}{l}19.55^{*} \\
(6.15)\end{array}$ \\
\hline Imputation controls & yes & \\
\hline Country dummies & yes & \\
\hline Students [unit of observation] & 115406 & \\
\hline Schools [unit of clustering] & 2932 & \\
\hline $\mathrm{R}^{2}$ & 0.243 & \\
\hline $\mathrm{R}^{2}$ (without imputation controls) & 0.235 & \\
\hline
\end{tabular}

Significance levels (based on standard errors robust to clustering at the school level): ${ }^{*} 1 \% .-{ }^{+} 5 \% .-{ }^{\circ} 10 \%$. 